\title{
Amelioration of drought effects in wheat and cucumber by the combined application of super absorbent polymer and potential biofertilizer
}

\author{
Yongbin Li ${ }^{1}$, Haowen Shi ${ }^{1}$, Haowei Zhang ${ }^{1}$, Sanfeng Chen ${ }^{\text {Corresp. } 1}$ \\ ${ }^{1}$ State Key Laboratory of Agrobiotechnology and College of Biological Sciences, China Agricultural University, Beijing, China \\ Corresponding Author: Sanfeng Chen \\ Email address: chensf@cau.edu.cn
}

Biofertilizer is a good substitute for chemical fertilizer in sustainable agriculture, but its effects are often hindered by drought stress. Super absorbent polymer (SAP), showing good capacity of water absorption and retention, can increase soil moisture. However, limited information is available about the efficiency of biofertilizer amended with SAP. This study was conducted to investigate the effects of synergistic application of SAP and biofertilizers (Paenibacillus beijingensis BJ-18 and Bacillus sp. L-56) on plant growth, including wheat and cucumber. Potted soil was treated with different fertilizer combinations (SAP, BJ-18 biofertilizer, L-56 biofertilizer, BJ-18 + SAP, L-56 + SAP), and pot experiment was carried out to explore its effects on viability of inoculants, seed germination rate, plant physiological and biochemical parameters, and expression pattern of stress-related genes under drought condition. At day 29 after sowing, the highest viability of strain $P$. beijingensis BJ-18 (264 copies $n^{-1}$ gDNA) was observed in BJ-18 + SAP treatment group of wheat rhizosphere soil, while that of strain Bacillus sp. L-56 (331 copies $\mathrm{ng}^{-1} \mathrm{gDNA}$ ) was observed in the L-56 + SAP treatment group of cucumber rhizosphere soil. In addition, both biofertilizers amended with SAP could promote germination rate of seeds (wheat and cucumber), plant growth, soil fertility (urease, sucrose, and dehydrogenase activities). Quantitative real-time PCR analysis showed that biofertilizer + SAP significantly down-regulated the expression levels of genes involved in ROS scavenging (TaCAT, CSCAT, TaAPX, and CSAPX2), ethylene biosynthesis (TaACO2, CSACO1, and CSACS1), stress response (TaDHN3, TaLEA, and CSLEA11), salicylic acid (TaPR1-1a and CSPR1-1a), and transcription activation (TaNAC2D and CSNAC35) in plants under drought stress. These results suggest that SAP addition in biofertilizer is a good tactic for enhancing the efficiency of biofertilizer, which is beneficial for plants in response to drought stress. To the best of our knowledge, this is the first report about the effect of synergistic use of biofertilizer and SAP on plant growth under drought stress. 


\section{Amelioration of drought effects in wheat and cucumber by the combined application of super absorbent polymer and potential biofertilizer}

1 Yongbin $\mathrm{Li}^{\dagger}$, Haowen Shi ${ }^{\dagger}$, Haowei Zhang, Sanfeng Chen*

2 State Key Laboratory of Agrobiotechnology and College of Biological Sciences, China

3 Agricultural University, Beijing, P. R. China

$4 \dagger$ These authors have contributed equally to this work

5 * Correspondence: Sanfeng Chen

6 E-mail: chensf@cau.edu.cn

7 Tel.: +86-10-62731551 
9 ABSTRACT

10 Biofertilizer is a good substitute for chemical fertilizer in sustainable agriculture, but its effects

11 are often hindered by drought stress. Super absorbent polymer (SAP), showing good capacity of

12 water absorption and retention, can increase soil moisture. However, limited information is

13 available about the efficiency of biofertilizer amended with SAP. This study was conducted to

14 investigate the effects of synergistic application of SAP and biofertilizers (Paenibacillus

15 beijingensis BJ-18 and Bacillus sp. L-56) on plant growth, including wheat and cucumber. Potted

16 soil was treated with different fertilizer combinations (SAP, BJ-18 biofertilizer, L-56 biofertilizer,

17 BJ-18 + SAP, L-56 + SAP), and pot experiment was carried out to explore its effects on viability of

18 inoculants, seed germination rate, plant physiological and biochemical parameters, and expression

19 pattern of stress-related genes under drought condition. At day 29 after sowing, the highest

20 viability of strain $P$. beijingensis $\mathrm{BJ}-18$ (264 copies $\mathrm{ng}^{-1}$ gDNA) was observed in BJ-18 + SAP

21 treatment group of wheat rhizosphere soil, while that of strain Bacillus sp. L-56 (331 copies ng-1

22 gDNA) was observed in the L-56 + SAP treatment group of cucumber rhizosphere soil. In addition,

23 both biofertilizers amended with SAP could promote germination rate of seeds (wheat and

24 cucumber), plant growth, soil fertility (urease, sucrose, and dehydrogenase activities).

25 Quantitative real-time PCR analysis showed that biofertilizer + SAP significantly down-regulated

26 the expression levels of genes involved in ROS scavenging (TaCAT, CsCAT, TaAPX, and

$27 C s A P X 2)$, ethylene biosynthesis (TaACO2, CsACO1, and $C s A C S 1)$, stress response (TaDHN3,

28 TaLEA, and CsLEA11), salicylic acid (TaPR1-1a and CsPR1-1a), and transcription activation 
29 (TaNAC2D and CsNAC35) in plants under drought stress. These results suggest that SAP addition

30 in biofertilizer is a good tactic for enhancing the efficiency of biofertilizer, which is beneficial for

31 plants in response to drought stress. To the best of our knowledge, this is the first report about the

32 effect of synergistic use of biofertilizer and SAP on plant growth under drought stress. 


\section{INTRODUCTION}

35 Traditional agricultural practices have negative influences on continental ecosystem due to huge

36 inputs of chemical fertilizer (Simonsen et al., 2015), which has given rise to serious problems such

37 as soil degradation, genetic diversity loss, nitrous oxide emission, and nitrate leaching (Webb,

38 Harrison \& Ellis 2000; Kaur, Brar \& Dhillon 2007). Biofertilizer containing plant growth-

39 promoting rhizobacteria (PGPR) is an ideal candidate for reducing application of chemical

40 fertilizer in sustainable agriculture (Rajkumar et al. 2010; Choudhury, Kecskes \& Kennedy 2014).

41 Numerous studies have been reported with respect to growth promotion and biocontrol (Vrieze et

42 al., 2015) and colonization of PGPR in different plants. Some PGPR could promote plant growth

43 by enhancing phosphorus $(\mathrm{P})$ solubilization, nitrogen $(\mathrm{N})$ fixation, zinc solubilization, potassium

44 solubilization, and indole-3-acetic acid (IAA) production (Calvo et al., 2010; Khan et al., 2010;

45 Islam et al., 2013; Gontia-Mishra et al., 2016). Previous studies have confirmed the roles of

46 Pseudomonas, Azospirillum, Bacillus, Burkholderia, and Paenibacillus on the growth of pea,

47 strawberry, rice, rape, and maize, respectively (Chen et al., 2013b; Guerrero-Molina et al., 2015;

48 Oteino et al., 2015; Shakeel et al., 2015; Li et al., 2017). PGPR, such as Lysinibacillus sphaericus

49 ZA9, showed great potential in plant growth promotion and biocontrol (Naureen et al., 2017). The

50 inoculation with endophytic P. aeruginosa PW09 ameliorated both biotic (Sclerotium rolfsii) and

51 abiotic ( $\mathrm{NaCl}$ stress) stresses in cucumber seedlings (Pandey et al., 2012). Similarly, the tolerance

52 of chickpea to biotic (Sclerotinia sclerotiorum) and abiotic ( $\mathrm{NaCl}$ stress) stresses was also

53 significantly enhanced after inoculation with $P$. putida S1 or P. aeruginosa Cgr (Ankita et al., 
54 2014). The application of endophytic Burkholderia phytofirmans PsJN mitigated drought stress,

55 thereby improving the growth and development of wheat (Naveed et al., 2013). PGPR could also

56 successfully colonize the tissues of plants (Yang et al. 2013; Gontia-Mishra et al. 2016; Hao \&

57 Chen 2017; Wang et al. 2017). However, the application of some biofertilizers still remains

58 limitation (Zhang et al. 2012; Grady et al. 2016). The reason might be that the reproduction of

59 PGPR was affected by adverse climatic conditions (Zhang et al., 2012;Bashan et al., 2013) such as

60 limited precipitation. Therefore, in arid and semi-arid regions of northern China (Islam et al.,

61 2010), drought is a crucial limiting factor, and water shortage hindered the application of

62 biofertilizer in practices.

63 Drought stress is one of the most destructive environmental factors affecting agricultural

64 production worldwide (Gontia-Mishra et al., 2016). Wheat often suffered from periodic drought

65 stress in the growth cycle (Naveed et al., 2013; Naresh et al., 2014). Super absorbent polymer

66 (SAP), a macromolecular cross-linked and environmentally-friendly polymer, had high capacity

67 of water adsorption and retention (Johnson \& Veltkamp 1985), which is conductive to improving

68 seed germination and seedling survival. SAP could be degraded through physical or chemical

69 processes (Mikkelsen, 1994). Hence, increasing number of SAP commercial products have been

70 developed to raise water use efficiency, alleviate drought stress, improve soil physical properties

71 and increase crop yield (Terry et al., 1986; Mikkelsen, 1994; Gray, 2011). Hydrogel supply

72 enhanced soil moisture and seed germination rate (Rehman, Ahmad \& Safdar 2011). The

73 application of a hydrophilic polymer (Superab A200) increased dry matter accumulation and water 
74 use efficiency of maize (Dorraji, Golchin \& Ahmadi 2010). Most studies only focused on the

75 application effect of SAP alone or mixed with a chemical fertilizer, however, to the authors'

76 knowledge, studies on synergistic use of SAP with biofertilizer are rarely reported, particularly

77 under water deficit conditions.

78 It is of great significance to investigate whether the application of SAP can retain more water

79 and create a suitable environment for reproduction of inoculants.

80 Soil enzyme activity, as a susceptive indicator of soil health, has potential of comprehensively

81 evaluating soil microbial functional diversity and its functional changes (Hestrin \& Goldblum

82 1953; Lebrun et al. 2012). Some soil enzymes paticipate in N, P, C cycling (Hestrin \& Goldblum

83 1953), and microbial activity. N cycling is mainly governed by urease, protease, and asparaginase;

84 P cycling by alkaline and acidity phosphatase; $\mathrm{C}$ cycling by cellulase, sucrase, and $\beta$-glucosidase;

85 and microbial activity is regulated by catalase (Kandeler, Kampichler \& Horak 1996). Fusarium

86 could produce and secrete extracellular enzymes such as phosphatase (Meyer, Garber \& Shaeffer

87 1964). SAP application had little effect on soil microbial metabolism (Sojka, Entry \& Fuhrmann

88 2006), but it still needs more understanding regarding the effect of synergistic use of biofertilizer

89 and SAP on soil enzymes involved in C, N, P cycling, and microbial activity.

90 In this paper, two important but different crops (wheat: monocotyledon; cucumber: dicotyledon)

91 were selected to comparatively investigate the effects of synergistic use of biofertilizer and SAP

92 on the following aspects: (i) viability of inoculants and soil enzyme activity; (ii) seed germination

93 and plant growth promotion; (iii) plant biochemical indexes and expression of drought stress- 
94 related genes under severe drought condition (40\% relative soil moisture). Our results are expected

95 to popularize the synergistic use of biofertilizer and SAP, especially in the areas suffered from

96 long-term drought stress.

97 MATERIALS \& METHODS

98 Bacterial strains and potted plant soil

99 Table 1 details the bacteria used in this study.

100 The topsoil (0-20 cm depth) was collected from Shangzhuang Experimental Station of China

101 Agricultural University, Beijing, China $\left(40^{\circ} 08^{\prime} 12.15^{\prime \prime} \mathrm{N}, 116^{\circ} 10^{\prime} 44.83^{\prime \prime} \mathrm{E}, 50.21 \mathrm{~m}\right.$ above sea

102 level). After air-dried at room temperature, the soil was screened by a 10-mesh sieve to remove

103 plant residues and reduce soil heterogeneity. Then the soil was sterilized at $121^{\circ} \mathrm{Cfor} 30 \mathrm{~min}$. The

104 experimental soil were low $\mathrm{N}$-content sandy loam (pH: 7.7, Olsen-P: $7.3 \mathrm{mg} \mathrm{kg}{ }^{-1}, \mathrm{~N}_{\min }: 7.8 \mathrm{mg} \mathrm{kg}^{-1}$,

$105 \mathrm{NH}_{4} \mathrm{OAc}-\mathrm{K}: 115.8 \mathrm{mg} \mathrm{kg}^{-1}$, organic matter, $\left.7.2 \mathrm{~g} \mathrm{~kg}^{-1}\right)$.

106 Preparation of biofertilizer and super absorbent polymer (SAP)

107 Two PGPR, P.beijingensis BJ-18 and Bacillus sp. L-56, were inoculated in Erlenmeyer flasks

$108(250 \mathrm{~mL})$ containing $100 \mathrm{~mL}$ of Luria Bertani (LB) broth and cultured at $30^{\circ} \mathrm{Cfor} 36 \mathrm{~h}$ at $180 \mathrm{rpm}$,

109 respectively. The culture was centrifuged at $6000 \mathrm{rpm}$ for $5 \mathrm{~min}$ and adjusted to $5 \times 10^{8}$ cells $\mathrm{mL}^{-1}$

110 with sterile normal saline $(0.89 \% \mathrm{w} / \mathrm{v} \mathrm{NaCl}$ in water $)$. Rice hull was used as carrier, which was

111 ground and screened by a 200 -mesh sieve. Then the powder was sterilized at $121^{\circ} \mathrm{C}$ for $20 \mathrm{~min}$. 
112 The above bacterial suspension was mixed aseptically with sterile rice hull powder (1:1, v/w), and

113 then the mixture was air dried separately in shade as biofertilizer.

114 The SAP used in this study is polyacrylamide (Dongying Huaye New Material Co., Ltd), which

115 is developed for agriculture and forestry use only. It was sterilized by ultraviolet (UV) light for $1 \mathrm{~h}$

116 in super clean bench (SW-CJ-1F(D)/2F(D), AIRTECH, China), and then mixed with biofertilizer

$117(1: 100, \mathrm{w} / \mathrm{w})$ according to the instructions of SAP.

\section{Plant culture and collection}

119 The experiment was performed to evaluate the role of SAP + biofertilizer under drought

120 condition. Plastic pots ( $35 \mathrm{~cm}$ in diameter; $25 \mathrm{~cm}$ in height), which were sterilized by soaking in

$1210.5 \mathrm{~N}$ nitric acid for $24 \mathrm{~h}$, were filled with the above sterilized soil $(5 \mathrm{~kg})$. The treatments were

122 listed in Table 2. The mixture (rice hull powder, biofertilizer, and SAP) of each treatment was

123 applied as base manure ( $9 \mathrm{~g} /$ per pot). Before sowing, the pots were watered to $40 \%$ relative soil

124 moisture by weighing method. Then, the plants were watered (200 mL each pot) every 5 days till

125 harvest.

126 Seed germination assay

127 For assessment of seed germination, plump seeds of wheat and cucumber were surface sterilized

128 with sodium hypochlorite $(10 \% \mathrm{v} / \mathrm{v})$ for $10 \mathrm{~min}$, followed by rinsing with sterile deionized water.

129 One hundred seeds of each plant were sown in each plastic pot. The experiment design was

130 completely randomized with three replicates for each treatment. The pots were arranged to the 
131 greenhouse under optimum condition $\left(15 \mathrm{~h}\right.$ day $/ 25^{\circ} \mathrm{C}-30^{\circ} \mathrm{C} /$ day temperature and $9 \mathrm{~h} \mathrm{night} / 15^{\circ} \mathrm{C}$ -

$13220^{\circ} \mathrm{C} /$ night temperature).

133 The numbers of germinated seeds were recorded daily from 6 days to 14 days after sowing, and

134 the germination rate was calculated according to the reported method (Sudisha et al., 2010).

135 Viability assessment of inoculants in rhizosphere soil

136 Two weeks after sowing, the seedlings (wheat and cucumber) were thinned to about $10 \mathrm{~cm}$ apart,

137 with only nine uniform and healthy seedlings were left in each pot. At the same time, the mixture

138 (rice hull powder, biofertilizer, and SAP) was applied again according to the description of Table 2

$139(9 \mathrm{~g} /$ per pot, ignoring the weight of SAP). To analyze the viability of inoculants in the rhizosphere

140 soil, the population density was measured by quantitative PCR (qPCR) (Savazzini et al., 2008) at

141 day $14,19,24,29,34,39$, and 44 after sowing. In order to collect the rhizosphere soil, the seedling

142 was uprooted and shaken gently to remove the loosely adhering soil, and the tightly adhering soil

143 regarded as rhizosphere soil. For the qPCR counting, DNA was extracted form rhizosphere soil

144 using an TIANamp Soil DNA Kit (Tiangen Biotech CO., LTD., Beijing, China) according to the

145 manufacturer's protocol. Suitable primers for qPCR were designed based on nifB of $P$.

146 beijingensis BJ-18 and amye of Bacillus sp. L-56 with the AlleleID 6.01 (PREMIER Biosoft

147 International, Palo Alto CA, USA; Table 3). The $107 \mathrm{bp} \mathrm{(nifB)}$ and $138 \mathrm{bp}$ (amye) fragments were

148 amplified by conventional PCR and then gel-purified. The PCR products were ligated to PMD 19-

149 T Vector (Takara, Otsu, Japan) and transformed into Escherichia coli JM109 competent cells by 
150 electrotransformation. The successfully transformed E. coli JM109 was cultured in LB liquid

151 medium, afterwards, the plasmids were extracted and purified using a TIANprep Mini Plasmid Kit

152 (TIANGEN BIOTECH(BEIJING) CO., LTD). A standard curve was generated for each run with a

153 dilution range of the recombinant plasmids from $2 \times 10^{1}$ to $2 \times 10^{7}$ copies. The above gDNA

154 isolated from different treatments was mixed with the SYBR ${ }^{\circledR}$ Premix Ex Taq ${ }^{\mathrm{TM}}$ (Takara, Kyoto,

155 Japan), primer pairs and $\mathrm{ddH}_{2} \mathrm{O}$ to a total volume of $20 \mathrm{uL}$ for qPCR. Target DNA was quantified

156 based on the above standard curve.

157 Sample collection and preparation

158 The plant and rhizosphere soil samples of wheat and cucumber were harvested at 44 days after

159 sowing. The growth parameters, i.e., root length, shoot length and fresh weight (FW) of each plant,

160 were immediately determined. Four plants per pot were oven dried at $105^{\circ} \mathrm{C}$ for $30 \mathrm{~min}$, followed

161 by $65^{\circ} \mathrm{C}$ for $72 \mathrm{~h}$. The dry weight (DW) was recorded. Chlorophyll content of seedlings was

162 determined at 8:30-9:30 am on the harvest day using the SPAD-502 chlorophyll meter (Minolta

163 Camera Co. Ltd. Japan). The remaining plant samples were rapidly frozen in liquid $\mathrm{N}$ and then

164 stored at $-80^{\circ} \mathrm{C}$ for further use. Rhizosphere soil samples were screened by a 10-mesh sieve, and

165 then stored in plastic bags for soil enzyme activity determination.

166 Determination of free proline content and total soluble sugars (TSS) in plant leaves

167 Under drought stress, accumulation of osmolytes (free proline content and total soluble sugars)

168 can promote cell growth under adverse osmotic conditions under adverse osmotic conditions. 
169 (Sandhya et al. 2010). Free proline content in leaves was measured using acid ninhydrin (Sharma

170 et al., 2010), and total soluble sugars (TSS) was determined using anthrone reagent (Shukla,

171 Agarwal \& Jha 2012).

172 Soil enzyme activity determination

173 A total of $5 \mathrm{~g}$ soil was taken to measure activities of enzymes, which was related to $\mathrm{N}$ cycling:

174 urease (EC 3.5.1.5); P cycling: alkaline phosphatase (EC 3.1.3.1) and acid phosphatase (EC

175 3.1.3.2); C cycling: invertase (EC 3.2.1.26) as well as microbial activity: dehydrogenase (EC

176 1.1.1). Urease activity was determined with urea as a substrate (Kaur, Brar \& Dhillon 2007) and

177 the released $\mathrm{N}-\mathrm{NH}_{4}{ }^{+}$amount $\left(\mathrm{mg} \mathrm{N}-\mathrm{NH}_{4}{ }^{+} \mathrm{g} \mathrm{soil}^{-1} \mathrm{~h}^{-1}\right)$ was determined spectrophotometrically at

$178 \mathrm{OD}_{578}$. Alkaline phosphatase and acid phosphatase were assessed with $p$-nitrophenyl phosphate as

179 a substrate (Tabatabai \& Bremner 1969) and the released $p$-nitrophenol (pNP) amount (mg pNP g

180 soil $\left.^{-1} \mathrm{~h}^{-1}\right)$ was measured spectrophotometrically at $\mathrm{OD}_{660}$. Sucrase activity was measured with

181 sucrose as a substrate (Chen et al., 2013a) and the released glucose amount (mg glucose $\mathrm{g} \mathrm{soil}^{-1} \mathrm{~h}^{-1}$ )

182 was determined spectrophotometrically at $\mathrm{OD}_{508}$. Dehydrogenase activity was determined with

183 2,3,5-triphenyltetrazolium chloride (TTC) as a substrate (Schinner et al., 1996) and the reduced

184 triphenylformazan (TPF) amount (mg TPF $\left.\mathrm{g} \mathrm{soil}^{-1} \mathrm{~h}^{-1}\right)$ was determined spectrophotometrically at

$185 \mathrm{OD}_{485}$. All assays were carried out in triplicate.

\section{Quantitative real-time (qRT) PCR analysis of drought stress-related genes}


187 Total RNA was extracted from leaf samples of wheat and cucumber using Trizol reagent

188 according to the manufacturer's protocol. RNA concentration was determined at $260 \mathrm{~nm}$ using a

189 spectrophotometer (Nanodrop 1000, Thermo Scientific, USA). Strand cDNA was synthesized

190 using PrimeScript ${ }^{\mathrm{TM}}$ RT reagent kit (Takara, Japan) following the instructions of the manufacturer.

191 Then, cDNA was used as template to determine gene expression levels. qRT-PCR was performed

192 by using the SYBR ${ }^{\circledR}$ Premix Ex Taq ${ }^{\mathrm{TM}}$ (TaKaRa, Kyoto, Japan). The specific primers of $A C T I N$

193 were used as reference. The specific primers used for qRT-PCR were designed by using the

194 AlleleID 6.01 (PREMIER Biosoft International, Palo Alto CA, USA) or from previous literature

195 (Table 3). The relative expression levels were calculated according to the standard comparative

$196 C(t)$ method (Livak \& Schmittgen 2001). Each treatment had three biological replicates, with three

197 technical replicates for each biological replicate.

\section{Statistical analysis}

199 All data was statistically analyzed using SPSS software version 20 (SPSS Inc., Chicago, IL,

200 USA). The significant differences among treatments were analyzed using one-way analysis of

201 variance (ANOVA) followed by least significant difference (LSD) at 0.05 level of probability.

202 Graphs were prepared with SigmaPlot software version 12.5 (Systat Software, Inc, California, 203 USA).

\section{RESULTS}




\section{Effects of biofertilizer and SAP on seed germination}

206 The number of germination seeds was dynamically observed from day 5 to day 14 after sowing

207 (Table 4). The synergistic use of biofertilizer and SAP had significant effects on germination rate

208 and germination time of wheat and cucumber seeds. The germination time of wheat seeds treated

209 with biofertilizer + SAP shortened by 4 days compared with that of the control, while 2 days

210 compared with that of SAP treatment group. The germination rate of wheat seeds was $22.70 \%$ in

211 the control; while $70.0 \%$ in BJ-18 + SAP treatment group and $62.0 \%$ in L-56 + SAP treatment

212 group. The results indicated that adding SAP to the biofertilizer of P. beijingensis BJ-18 and

213 Bacillus sp. L-56 increased the seed germination rate by $47.3 \%$ and $39.3 \%$, respectively, compared

214 with the control.

215 Similarly, biofertilizer + SAP treatment group shorten the germination time of cucumber seed

216 by 2-4 days compared with other treatment groups. Among all the treatments of cucumber, L-56 +

217 SAP treatment group had the highest germination rate, with a 35.7\% increase compared to the L-

21856 treatment group.

219 Effect of biofertilizer and SAP on viability of inoculant

220 The qPCR method was used to determine the inoculant population density in the rhizosphere

221 soil, and the viability of inoculants was significantly enhanced when biofertilizer was applied with

222 SAP as compared to other treatments (Table 5). The inoculant populations increased at first and

223 then declined. In wheat rhizosphere, the strain of BJ-18 + SAP treatment group showed the highest 
224 bacterial population (264 copies $\mathrm{ng}^{-1}$ gDNA) at day 29 after sowing. After reaching the highest

225 population, both strains of $P$. beijingensis BJ-18 and Bacillus sp. L-56 showed a continuous

226 declining trend. In cucumber rhizosphere, the L-56 + SAP treatment group showed the highest

227 bacterial population (331.7 copies $\mathrm{ng}^{-1} \mathrm{gDNA}$ ) at day 29; and retained a higher level (75.0 copies

$228 \mathrm{ng}^{-1} \mathrm{gDNA}$ ) till day 44 than others. No such inoculants (P. beijingensis BJ-18 and Bacillus sp. L-

229 56) populations were detected in the rhizosphere soil of un-inoculated seedlings (wheat and

230 cucumber).

\section{Effect of biofertilizer and SAP on plant growth parameters}

232 The treatments of adding SAP to biofertilizer significantly increased the growth parameters of

233 both wheat and cucumber seedlings, including plant length, FW and DW (Fig. 1). The BJ-18+

234 SAP treatment group showed maximum increase over control in shoot length (28.2\%), root length

235 (42.3\%), shoot FW (86.9\%), root FW (83.4\%), shoot DW (104.9\%) and root DW (79.7\%) of

236 wheat seedlings. However, no significant effect was found in BJ-18 treatment group and L-56

237 treatment group in comparison to control.

238 In case of cucumber plants, the treatment group of L-56 + SAP showed maximum increase over

239 control in shoot length (47.8\%), root length (50.8\%), shoot FW (71.9\%), root FW (175.7\%), shoot

240 DW (68.9\%) and root DW (76.9\%). All the biometric growth parameters showed an order of L-56

$241+$ SAP $>$ BJ-18 + SAP $>$ L-56 $>$ BJ-18 $>$ Control. Similarly, cucumber treated with biofertilizer

242 alone had no significant difference in all the biometric growth parameters as compared to control. 
243 Effect of biofertilizer and SAP on biochemical parameters of seedlings

244 For both wheat and cucumber, the biochemical parameters (proline content, TSS content, and

245 chlorophyll content) of leaves were quantified (Fig. 2). The results indicated that L-56 + SAP

246 treatment group showed the lowest proline content, followed by BJ-18 + SAP group. The

247 seedlings also showed a significant decline in total soluble sugar content in contrast to

248 corresponding control. The chlorophyll content was expressed as SPAD value. A significant

249 increase in chlorophyll content of both wheat and cucumber seedlings was observed in the BJ-18+

250 SAP treatment group compared to corresponding control (SPAD value of 59.0 and 46.3,

251 respectively).

252 Effect of biofertilizer and SAP on soil extracellular enzyme activities

253 The activities of extracellular enzymes (urease, sucrose, acid phosphate, alkaline phosphate, and

254 catalase) in rhizosphere soil were determined (Fig. 3). In the wheat and cucumber rhizosphere soil,

255 urease activity in the BJ-18 + SAP group was greater than others (Fig. 3A). The BJ-18 + SAP

256 treatment had significant positive effects on sucrose activity of the wheat rhizosphere soil as

257 compared to control (Fig. 3B). However, the L-56 + SAP group showed the lowest sucrose activity

258 in the cucumber rhizosphere soil (Fig. 3B). It was observed that the activity of alkaline

259 phosphatase in different treatments was higher than that of acid phosphatase, and all treatment

260 groups showed no significant difference in both acid and alkaline phosphatase activities in

261 comparison to corresponding control (Fig. 3C and 3D). In the Figure 3E, the dehydrogenase 
262 activity was the lowest in BJ-18 + SAP group of wheat rhizosphere soil, while it was the lowest in

263 the L-56 + SAP group of cucumber rhizosphere soil.

\section{Effect of PGPR and SAP on expression of stress-responsive genes}

265 The qRT-PCR results showed the drought stress-related genes had different expression patterns

266 under drought stress in biofertilizer + SAP treatment group and SAP treatment group (Fig. 4). The

267 transcript levels of TaCAT, TaAPX, TaACO, TaDHN, TaLEA, TaPRI, and TaNAC were down-

268 regulated in wheat treated with BJ-18+SAP and L-56 + SAP as compared to the control.

269 Variability in expression was also observed in the cucumber seedlings. The transcript levels of

$270 C s C A T, C s A P X, C s A C O, C s A C S, C s L E A, C s P R 1$, and $C s N A C$ were down-regulated in cucumber

271 treated with BJ-18+SAP and L-56 + SAP as compared to the control

272 DISSCUSSION

273 Water deficiency suppresses PGPR reproduction of biofertilizer in the arid and semiarid areas of

274 North China, and the application of biofertilizer was limited because no positive effect on crop

275 growth and yield was observed. This study was aimed at minimizing the negative effect of water

276 deficiency on biofertilizer by adding SAP to biofertilizer. The results revealed that synergistic use

277 of biofertilizer and SAP decreased adverse effect of water deficiency on PGPR, and improved the 278 efficiency of biofertilizer. 
279 Germination is one of the most vital stages in a crop life cycle, which is significantly impacted

280 by drought stress (Sleimi et al., 2013). Both SAP treatment group and PGPR + SAP treatment

281 group significantly enhanced the germination rate of wheat and cucumber seeds. The use of SAP

282 could improve the water-holding capacity of soil (Johnson, 1984), which is beneficial to seed

283 germination. The application of SAP improved Caragana korshinskii seed germination rate (Su et

284 al., 2017). Inoculation with PGPR (P. fluorescens, Enterobacter hormaechei, and P. migulae)

285 could promote foxtail millet seed germination and seedling growth under drought condition (Niu

286 et al., 2018). PGPR of Burkholderia sp. L2 and Bacillus sp. A30 could increase tomato seed

287 germination (Tripti et al., 2017). In addition, the inoculation of Pseudomonas, Azospirillum, and

288 Azotobacter significantly improve maize seed germination (Gholami, Shahsavani \& Nezarat

289 2009). In this study, the SAP application created an optimal environment for PGPR reproduction

290 and seed germination by increasing soil moisture. Therefore, both BJ-18 + SAP and L-56 + SAP

291 groups presented the maximum germination rate of wheat and cucumber.

292 The survival and persistence of PGPR introduced into rhizospher soil is a most vital factor for

293 successful application of biofertilizer (Naqqash et al., 2016). Here, the survival and persistence of

294 inoculants (P. beijingensis BJ-18 and Bacillus sp. L-56) in the rhizosphere soil was dynamically

295 observed during the period of day 14-44 using qPCR. All groups except control exhibited

296 consistent trend in populations of inoculants, which were increased firstly and declined afterwards.

297 Similar trend has been observed in the strain of Phomopsis liquidambari (Wang et al., 2014). In

298 general, the combination use of biofertilizer and SAP significantly increased the bacterial 
299 populations compared with corresponding biofertilizer use alone, in both wheat and cucumber

300 rhizosphere soil. Even at day 44, the largest bacterial population was observed in BJ-18 + SAP

301 group of wheat rhizosphere (68.5 copies $\mathrm{ng}^{-1}$ gDNA), and in L-56 + SAP group of cucumber

302 rhizosphere (75.0 copies $\mathrm{ng}^{-1}$ gDNA). Numerous studies have reported the populations of

303 introduced microorganisms were significantly reduced in the natural soil (Pujol et al. 2006; Kumar,

304 Trivedi \& Pandey 2007; Longa et al. 2009) due to the hostility of adverse biotic factor

305 (competition with native organisms for finite nurture) and abiotic factors (temperature, humidity,

$306 \mathrm{pH}$ values) within the soil (Avrahami \& Bohannan 2007). Our results indicated that adding SAP to

307 biofertilizer could minimize the adverse effect of water deficiency, thus improving the inoculant

308 viability and prolonging persistence. It has been reported that the population density of Pseudome

309 fluorescents in biochar and/or compost treated soil significantly higher than that in un-treated soil,

310 which is achieved by increasing soil moisture (Nadeem et al., 2017).

311 In wheat and cucumber, both BJ-18 group and L-56 group did not significantly improve plant

312 growth parameters (length, FW, DW) as compared to the control, which was not consistent with

313 the results of previous studies, where Klebsiella sp. MBE02, Paenibacillus sp. NSY50, Bacillus,

314 and Pseudomonas sp. MS16 enhanced the growth of peanut, cucumber, rice, wheat and

315 respectively (Sharma, Kulkarni \& Jha 2016; Du et al. 2016; Feng et al. 2017; Muhammad et al.

316 2018). However, with the combination use of SAP (BJ-18 + SAP group and L-56 + SAP group),

317 the above parameters (length, FW, DW) were significantly elevated in both wheat and cucumber

318 seedlings as compared to the corresponding control. Particularly, BJ-18 + SAP treatment 
319 significantly promoted the root length, root FW, shoot DW and root DW compared with the SAP

320 treatment in wheat, and also increased shoot FW, shoot FW and shoot DW in cucumber; L-56 +

321 SAP treatment significantly promoted the shoot FW, root FW and shoot DW in wheat compared

322 with the SAP treatment, and also increased shoot FW and shoot DW in cucumber. Considering the

323 water-holding capacity of SAP, it was hypothesized that SAP is conductive to creating a more

324 suitable environment for the reproduction of introduced inoculants in soil under drought stress.

325 Such hypothesis was proven by the fact that survival of $P$. beijingensis BJ-18 and Bacillus sp. L-56

326 was greater in SAP treated soil as compared to the un-amended soil.

327 After application of biofertilizer amended with SAP in wheat and cucumber, the activities of

328 urease, sucrose and dehydrogenase were significantly increased as compared the control. Urease

329 increased utilization of $\mathrm{N}$ fertilizer by catalysing urea hydrolysis into ammonia (Bowles et al.,

330 2014). No matter for wheat or cucumber, the BJ-18 + SAP group showed the strongest urease

331 activity in all treatments, which might be related to the $\mathrm{N}$-fixing ability of $P$. beijingensis BJ-18

332 (Wang et al., 2013). The activity of dehydrogenase, a vital indicator of microorganism activity,

333 was increased after the application of inoculation to soil (Siddikee et al., 2016). Here, the highest

334 activity of dehydrogenase and sucrose was detected in the BJ-18 + SAP group of wheat

335 rhizosphere soil and L-56 + SAP group of cucumber rhizosphere soil, which was consistent with

336 the survival of $P$. beijingensis BJ-18 and Bacillus sp. L-56 in the wheat or cucumber rhizosphere

337 soil. These findings were also consistent with previous report (Xun et al., 2015), which

338 demonstrates that inoculation with PGPR could significantly enhance the activities of soil 
339

340

341

342 343

344

345

346

347

348

enzymes (urease, dehydrogenase, and sucrose). However, acid phosphatase (alkaline phosphatase)

activity showed no significant difference among different treatments, indicating that these two inoculants have little effects on this enzyme. In addition, the activity of alkaline phosphatase in different treatments was higher than that of acid phosphatase, which might be related to the influence of alkaline soil. Similar results have been reported in rice inoculated with Phomopsis liquidambari under LN level (Siddikee et al., 2016).

Under drought stress, the accumulation of proline and total soluble sugar can protect plant cells from osmotic damage (Delauney \& Verma, 1993;Gontia-Mishra et al., 2016; Tiwari et al., 2016). Accordingly, a reduction in proline and total soluble sugar content was observed in both wheat and cucumber seedlings in the SAP treatment group compared with control, BJ-18 and L-56

treatments. However, wheat and cucumber showed a further decrease in proline and total soluble sugar in the BJ-18 + SAP and L-56 + SAP treatments as compared with SAP treatment group. It was obvious that SAP amendment could help the biofertilizer to perform better by providing a suitable habitat for inoculants in soil, and therefore, less proline and total soluble sugar were accumulated by synergistic use of biofertilizer and SAP. Under drought stress, less proline accumulation of Caragana korshinskii grown in SAP amended soil was also reported by (Su et al., 2017). Chlorophyll content is also significant biochemical indicator of stress tolerance in plants (Percival, Fraser \& Oxenham 2003). In this study, the BJ-18 + SAP and L-56 + SAP treatments significantly improved the chlorophyll content in the wheat and cucumber seedlings. The application of biochar could also increase the chlorophyll content of Chenopodium quinoa by 
359 improving soil moisture content (Gorim \& Asch, 2017). PGPR-inoculated plants also showed a

360 significant increase in chlorophyll content (Kakar et al., 2016; Abdelkrim et al. 2018; El-Esawi et

361 al. 2018).

362 To better understand how the plants (wheat and cucumber) respond to the different treatments at

363 the transcriptional level, some representative drought-responsive genes were selected. Both $C A T$

364 and $A P X$ genes were involved in reactive oxygen species (ROS) scavenging, and ROS

365 overproduction resulted in a negative oxidative stress on plant growth. (Lata et al., 2011; Tiwari et

366 al., 2016). qRT-PCR analysis showed that under drought stress, the expression levels of $A P X$ and

367 CAT in seedlings of the biofertilizer + SAP groups were lower than those of other treatment groups,

368 suggesting that biofertilizer + SAP treatments could relieve drought stress and ensure normal

369 growth of seedlings. It was also reported chickpea inoculated with Pseudomonas showed

370 significantly lower expression of $C A T$ and $A P X$ during the stress period (Tiwari et al., 2016; Saif \&

371 Khan 2018). Ethylene has been reported to regulate some different aspects of plant growth and

372 development, particularly abiotic stressed such as drought stress (Yang, Kloepper \& Ryu 2009;

373 Habben et al. 2014). Both $A C O$ and $A C S$ are involved in ethylene metabolism. In this study, the

374 biofertilizer + SAP treatments significantly repressed the expression levels of $C A T$ and $A P X$,

375 indicating less ethylene accumulation in plants treated with biofertilizer + SAP. Dehydrin and late

376 embryogenesis abundant protein encoded by $D H N$ and $L E A$ genes play great roles in adaptive

377 responses of plants to drought stress (Gao et al., 2008). The biofertilizer + SAP groups showed

378 relatively low expression level of $D H N$ and $L E A$. There were plenty of evidence for the 
379 involvement of salicylic acid in plant drought stress (Fujita et al., 2006). PRl participate in

380 salicylic acid metabolism. In this study, the biofertilizer + SAP treatments significantly inhibited

381 the expression of $P R 1$. NAC transcription factors have been reported to participate in biotic and

382 abiotic stress tolerance in plants (Delessert et al. 2005; Nakashima, Ito \& Yamaguchi-Shinozaki

383 2009; Wu et al., 2009). TaNAC2D was induced by abiotic stress (Huang \& Wang, 2016) and

384 CsNAC22 responded to drought stress (Zhang et al., 2017). In this study, the biofertilizer + SAP

385 groups inhibited the expression of $N A C$. Taken together, our results suggest that the biofertilizer +

386 SAP treatments significantly ameliorate drought stress.

387 CONCLUSIONS

388 This study showed that the addition of SAP significantly enhanced survival rate of inoculants $(P$.

389 beijingensis BJ-18 and Bacillus sp. L-56), and then promoted seed germination of wheat and

390 cucumber, plant growth, soil fertility (urease, sucrose and dehydrogenase). qRT-PCR analysis also

391 showed that the transcript levels of some stress-related genes were down-regulated in wheat and

392 cucumber treated with biofertilizer + SAP, respectively, which imply that the biofertilizer + SAP

393 treatments contribute to drought tolerance of wheat and cucumber. Our results indicate that SAP

394 addition in biofertilizer is a good strategy for improving the efficiency of biofertilizer, especially in

395 the areas suffered from long-term drought stress. This study was carried out in the greenhouse,

396 therefore, further experiments are still needed to confirm the effect of biofertilizer amended with

397 SAP in the field. 


\section{Acknowledgements}

400 We would like to thank Caixia Wang for helping to improve manuscript.

401 


\section{Figure captions}

403 Figure 1: Effects of super absorbent polymer supply on shoot length (A), root length (B), shoot

404 fresh weight (C), root fresh weight (D), shoot dry weight (E) and root dry weight (F) of wheat and 405 cucumber seedlings.

406 Values are given as mean of three independent biological replicates, and bearing different letters

407 (a, b, c) are significantly different from each other according to the least significant difference

408 (LSD) test $(\mathrm{p}<0.05)$. The bars represent the standard error. SAP: Super Absorbent Polymer, BJ-18:

409 P. beijingensis strain BJ-18, L-56: Bacillus sp. strain L-56.

410 Figure 2: Effects of super absorbent polymer supply on proline concentration (A), total soluble

411 sugar concentration (B), chlorophyll content (C) of wheat and cucumber seedlings.

412 Values are given as mean of three independent biological replicates, and bearing different letters (a,

413 b, c) are significantly different from each other according to the least significant difference (LSD)

414 test $(\mathrm{p}<0.05)$. The bars represent the standard error. SAP: Super Absorbent Polymer, BJ-18: P.

415 beijingensis strain BJ-18, L-56: Bacillus sp. strain L-56.

416 Figure 3: Effects of super absorbent polymer supply on enzyme activities of urease (A), sucrose

417 (B), alkaline phosphatase (C), acid phosphatase (D) and dehydrogenase (E) of rhizosphere soil.

418 The values are given as mean of three independent biological replicates, and bearing different

419 letters $(a, b, c)$ are significantly different from each other according to the LSD test $(p<0.05)$. The 
420 bars represent the standard error. SAP: Super Absorbent Polymer, BJ-18: P. beijingensis strain BJ-

421 18, L-56: Bacillus sp. strain L-56, pNP: p-Nitrophenol, TPF: Triphenylformazan.

422 Figure 4: Effects of super absorbent polymer supply on relative gene expression level of stress-

423 genes in wheat and cucumber seedlings.

424 The values are given as mean of three independent biological replicates, and bearing different

425 letters $(\mathrm{a}, \mathrm{b}, \mathrm{c})$ are significantly different from each other according to the least significant

426 difference (LSD) test $(\mathrm{p}<0.05)$. The bars represent the standard error. SAP: Super Absorbent

427 Polymer, BJ-18: P. beijingensis strain BJ-18, L-56: Bacillus sp. strain L-56. a: DHN for wheat,

$428 A C S$ for cucumber.

429 Table caption

430 Table 1: Bacterial cultures and genomes used in this study.

431 Table 2: Description of treatments used for pot experiment.

432 Table 3: Primers sequence and accession number in NCBI.

433 Table 4: Effects of super absorbent polymer supply on germination of wheat and cucumber seeds.

434 Values are given as mean $\pm \mathrm{SE}$ of three independent biological replicates, and bearing different

435 letters (a, b, c) at one specific time (e.g. 5 or 6 days) are significantly different from each other

436 according to the least significant difference (LSD) test $(p<0.05)$; D: days.

437 Table 5: Survival of different bacterial strains inoculated to plants (wheat and cucumber) and

438 population dynamics in the rhizosphere after thinning. 
439 Values are given as mean $\pm \mathrm{SE}$ of three independent biological replicates, and bearing different

440 letters $(\mathrm{a}, \mathrm{b}, \mathrm{c})$ at one specific time (e.g. 14 or 19 days) are significantly different from each other

441 according to the LSD test $(\mathrm{p}<0.05)$; D: days; ND: not detected.

442 


\section{REFERENCE}

444

445

446

447

448

449

450

451

452

453

454

455

456

457

458

459

460

461

462

463

464

465

466

467

468

469

470

471

Abdelkrim S, Jebara SH, Saadani O, and Jebara M. 2018. Potential of efficient and resistant plant growth-promoting rhizobacteria in lead uptake and plant defence stimulation in Lathyrus sativus under lead stress. Plant Biology 20:857-869 DOI 10.1111/plb.12863.

Ankita S, Singh PJ, Sudheer Y, Sarma BK, Singh SJ, Singh HB. 2014. Studies on rhizospherebacteria mediated biotic and abiotic stress tolerance in chickpea (Cicer arietinum L.). Vegetos 27(1):158-169 DOI 10.5958/j.2229-4473.27.1.025.

Avrahami S, Bohannan BJ. 2007. Response of Nitrosospira sp. strain AF-like ammonia oxidizers to changes in temperature, soil moisture content, and fertilizer concentration. Applied and Environmental Microbiology 73(4):1166-1173 DOI 10.1128/AEM.01803-06.

Bashan Y, de-Bashan LE, Prabhu SR, Hernandez J-P. 2013. Advances in plant growthpromoting bacterial inoculant technology: formulations and practical perspectives (19982013). Plant and Soil 378(1-2):1-33 DOI 10.1007/s11104-013-1956-x.

Bowles TM, Acosta-Martínez V, Calderón F, Jackson LE. 2014. Soil enzyme activities, microbial communities, and carbon and nitrogen availability in organic agroecosystems across an intensively-managed agricultural landscape. Soil Biology and Biochemistry 68:252-262 DOI 10.1016/j.soilbio.2013.10.004.

Calvo P, Ormeno-Orrillo E, Martinez-Romero E, Zuniga D. 2010. Characterization of Bacillus isolates of potato rhizosphere from andean soils of peru and their potential PGPR characteristics. Brazilian Journal of Microbiology 41:899-906 DOI 10.1590/S151783822010000400008 .

Chen J, Liu X, Zheng J, Zhang B, Lu H, Chi Z, Pan G, Li L, Zheng J, Zhang X, Wang J, Yu X. 2013a. Biochar soil amendment increased bacterial but decreased fungal gene abundance with shifts in community structure in a slightly acid rice paddy from Southwest China. Applied Soil Ecology 71:33-44 DOI 10.1016/j.apsoil.2013.05.003.

Chen ZJ, Sheng XF, He LY, Huang Z, Zhang WH. 2013b. Effects of root inoculation with bacteria on the growth, $\mathrm{Cd}$ uptake and bacterial communities associated with rape grown in Cd-contaminated soil. Journal of Hazardous Materials 244-245:709-717 DOI 10.1016/j.jhazmat.2012.10.063. 
472 Choudhury ATMA, Kecskes ML, Kennedy IR. 2014. Utilization of BNF technology

473

474

475

476

477

478

479

480

481

482

483

484

485

486

487

488

489

490

491

492

493

494

495

496

497

498

499

500

501

502

503

504 supplementing urea $\mathrm{N}$ for sustainable rice production. Journal of Plant Nutrition 37:16271647 DOI 10.1080/01904167.2014.888746.

Delauney A, Verma D. 1993. Proline biosynthesis and osmoregulation in plants. Plant Journal 4(2):215-223.

Delessert C, Kazan K, Wilson IW, Van Der Straeten D, Manners J, Dennis ES, Dolferus R. 2005. The transcription factor $A T A F 2$ represses the expression of pathogenesis-related genes in Arabidopsis. Plant Journal 43(5):745-757 DOI 10.1111/j.1365-313X.2005.02488.x.

Dong C-J, Li L, Shang Q-M, Liu X-Y, Zhang Z-G. 2014. Endogenous salicylic acid accumulation is required for chilling tolerance in cucumber (Cucumis sativus L.) seedlings. Planta 240(4):687-700 DOI 10.1007/s00425-014-2115-1.

Dorraji SS, Golchin A, Ahmadi S. 2010. The effects of hydrophilic polymer and soil salinity on corn growth in sandy and loamy soils. CLEAN - Soil, Air, Water:38(7):584-591 DOI 10.1002/clen.201000017.

Du N, Shi L, Yuan Y, Li B, Shu S, Sun J, Guo S. 2016. Proteomic analysis reveals the positive roles of the plant-growth-promoting Rhizobacterium NSY50 in the response of cucumber roots to Fusarium oxysporum f. sp. cucumerinum inoculation. Frontiers in Plant Science 7:1859 DOI 10.3389/fpls.2016.01859.

El-Esawi MA, Alaraidh IA, Alsahli AA, Alamri SA, Ali HM, and Alayafi AA. 2018. Bacillus firmus (SW5) augments salt tolerance in soybean (Glycine max L.) by modulating root system architecture, antioxidant defense systems and stress-responsive genes expression. Plant physiology and biochemistry 132:375-384. DOI 10.1016/j.plaphy.2018.09.026.

Feng F, Ge J, Li Y, He S, Zhong J, Liu X, Yu X. 2017. Enhanced degradation of chlorpyrifos in rice (Oryza sativa L.) by five strains of endophytic bacteria and their plant growth promotional ability. Chemosphere 184:505-513 DOI 10.1016/j.chemosphere.2017.05.178.

Fujita M, Fujita Y, Noutoshi Y, Takahashi F, Narusaka Y, Yamaguchi-Shinozaki K, Shinozaki K. 2006. Crosstalk between abiotic and biotic stress responses: a current view from the points of convergence in the stress signaling networks. Current Opinion in Plant Biology 9(4):436-442 DOI 10.1016/j.pbi.2006.05.014.

Gao WR, Wang XS, Liu QY, Peng H, Chen C, Li JG, Zhang JS, Hu SN, Ma H. 2008. Comparative analysis of ESTs in response to drought stress in chickpea (C. arietinum L.). Biochemical and Biophysical Research Communications 376(3):578-583 DOI 10.1016/j.bbrc.2008.09.030. 
505 Gholami A, Shahsavani S, Nezarat S. 2009. The effect of plant growth promoting rhizobacteria

506

507

508

509

510

511

512

513

514

515

516

517

518

519

520

521

522

523

524

525

526

527

528

529

530

531

532

533

534

535 (PGPR) on germination, seedling growth and yield of maize. Proceedings of World Academy of Science Engineering \& Technolog 49:19.

Gontia-Mishra I, Sapre S, Sharma A, Tiwari S. 2016. Amelioration of drought tolerance in wheat by the interaction of plant growth-promoting rhizobacteria. Plant Biology (Stuttg) 18(6):992-1000 DOI 10.1111/plb.12505.

Gorim L, Asch F. 2017. Seed coating increases seed moisture uptake and restricts embryonic oxygen availability in germinating cereal seeds. Biology (Basel) 6(2) DOI 10.3390/biology6020031.

Gray D. 2011. Fluid drilling of vegetable seeds. Horticultural Reviews 3:1-27 DOI 10.1099/ijs.0.013649-0.

Grady EN, MacDonald J, Liu L, Richman A, Yuan ZC, 2016. Current knowledge and perspectives of Paenibacillus: a review. Microbial Cell Factories 15(1): 203 DOI: 10.1186/s12934-016-0603-7.

Guerrero-Molina MF, Lovaisa NC, Salazar SM, Martinez-Zamora MG, Diaz-Ricci JC, Pedraza RO. 2015. Physiological, structural and molecular traits activated in strawberry plants after inoculation with the plant growth-promoting bacterium Azospirillum brasilense REC3. Plant Biology (Stuttg) 17(3):766-773 DOI 10.1111/plb.12270.

Habben JE, Bao X, Bate NJ, DeBruin JL, Dolan D, Hasegawa D, Helentjaris TG, Lafitte RH, Lovan N, Mo H, Reimann K, and Schussler JR. 2014. Transgenic alteration of ethylene biosynthesis increases grain yield in maize under field drought-stress conditions. Plant Biotechnology Journal DOI 12:685-693. 10.1111/pbi.12172.

Hao T, Chen S. 2017. Colonization of wheat, maize and cucumber by Paenibacillus polymyxa WLY78. PLoS One 12(1):e0169980 DOI 10.1371/journal.pone.0169980.

Hestrin S, Goldblum J. 1953. Lævanpolyas. Nature 172:1046-1047.

Huang Q, Wang Y. 2016. Overexpression of TaNAC2D Displays opposite responses to abiotic stresses between seedling and mature stage of transgenic Arabidopsis. Frontiers in Plant Science 7 DOI 10.3389/fpls.2016.01754.

Islam MR, Eneji AE, Changzhong R, Yuegao H, Gong C, Xuzhang X. 2010. Oatbasedcropping system for sustainable agricultural development in aridregions of northern China. Journal of Agriculture, Biotechnology \& Ecology 3(3):1-8. 
536 Islam MR, Sultana T, Joe MM, Yim W, Cho JC, Sa T. 2013. Nitrogen-fixing bacteria with

537

538

539

540

541

542

543

544

545

546

547

548

549

550

551

552

553

554

555

556

557

558

559

560

561

562

563

564

565

566

567 multiple plant growth-promoting activities enhance growth of tomato and red pepper. Journal of Basic Microbiology 53(12):1004-1015 DOI 10.1002/jobm.201200141.

Johnson MS. 1984. The effects of gel-forming polyacrylamides on moisture storage in sandy soils. Journal Science Food Agriculture 35(11):1196-1200.

Johnson MS, Veltkamp CJ. 1985. Structure and functioning of water-storing agricultural polyacrylamides. Journal Science Food Agriculture 36:789-793.

Kakar KU, Ren XL, Nawaz Z, Cui ZQ, Li B, Xie GL, Hassan MA, Ali E, Sun GC. 2016. A consortium of rhizobacterial strains and biochemical growth elicitors improve cold and drought stress tolerance in rice (Oryza sativa L.). Plant Biology (Stuttg) 18(3):471-483 DOI 10.1111/plb.12427.

Kandeler E, Kampichler C, Horak O. 1996. Influence of heavy metals on the functional diversity of soil microbial communities. Biology and Fertility of Soils 23(3):299-306 DOI 10.1007/BF00335958.

Kaur T, Brar BS, Dhillon NS. 2007. Soil organic matter dynamics as affected by long-term use of organic and inorganic fertilizers under maize-wheat cropping system. Nutrient Cycling in Agroecosystems 81(1):59-69 DOI 10.1007/s10705-007-9152-0.

Khan MS, Zaidi A, Ahemad M, Oves M, Wani PA. 2010. Plant growth promotion by phosphate solubilizing fungi-current perspective. Archives of Agronomy and Soil Science 56(1):73-98 DOI 10.1080/03650340902806469.

Kumar B, Trivedi P, Pandey A. 2007. Pseudomonas corrugata: A suitable bacterial inoculant for maize grown under rainfed conditions of Himalayan region. Soil Biology and Biochemistry 39(12):3093-3100 DOI 10.1016/j.soilbio.2007.07.003.

Lata C, Jha S, Dixit V, Sreenivasulu N, Prasad M. 2011. Differential antioxidative responses to dehydration-induced oxidative stress in core set of foxtail millet cultivars [Setaria italica (L.)]. Protoplasma 248:817-828 DOI 1007/s00709-010-0257-y).

Lebrun JD, Trinsoutrot-Gattin I, Vinceslas-Akpa M, Bailleul C, Brault A, Mougin C, Laval K. 2012. Assessing impacts of copper on soil enzyme activities in regard to their natural spatiotemporal variation under long-term different land uses. Soil Biology and Biochemistry 49:150-156 DOI 10.1016/j.soilbio.2012.02.027.

Li N, Zhang S, Liang YJ, Qi YH, Chen J, Zhu WN, Zhang LS. 2018. Label-free quantitative proteomic analysis of drought stress-responsive late embryogenesis abundant proteins in the 
568

569

570

571

572

573

574

575

576

577

578

579

580

581

582

583

584

585

586

587

588

589

590

591

592

593

594

595

596

597

seedling leaves of two wheat (Triticum aestivum L.) genotypes. Journal of Proteomics 172:122-142 DOI 10.1016/j.jprot.2017.09.016.

Li Y, Liu X, Hao T, Chen S. 2017. Colonization and maize growth promotion induced by phosphate solubilizing bacterial isolates. International Journal of Molecular Sciences 18(7) DOI 10.3390/ijms18071253.

Livak KJ, Schmittgen TD. 2001. Analysis of relative gene expression data using real-time quantitative PCR and the $2^{\text {(-Delta Delta C(T)) }}$ Method. Methods 25(4):402-408 DOI 10.1006/meth.2001.1262.

Longa CM, Savazzini F, Tosi S, Elad Y, Pertot I. 2009. Evaluating the survival and environmental fate of the biocontrol agent Trichoderma atroviride $\mathrm{SC} 1$ in vineyards in northern Italy. Journal of Applied Microbiology 106(5):1549-1557 DOI 10.1111/j.13652672.2008.04117.x.

Meyer JA, Garber ED, Shaeffer SG. 1964. Genetics of phytopathogenic fungi. XII. Detection of esterases and phosphatases in culture filtrates of Fusarium oxysporum and F. xylarioides by starch-gel zone electrophoresis. International Journal of Plant Sciences 125(4):298-300

Mikkelsen RL. 1994. Using hydrophilic polymers to control nutrient release. Nutrient Cycling in Agroecosystems 38(1):53-59.

Moloudi F, Navabpour S, S H, R SS, S H. 2013. Catalase and Metallothionein genes expression analysis in wheat cultivars under drought stress condition. JPMB 1:54-68 DOI 10.22058/JPMB.2013.3262.

Muhammad S, Sumera Y, Maria R, Mahreen Y, Babar MA, Muhammad SM. 2018. Phosphate solubilizing bacteria with glucose dehydrogenase gene for phosphorus uptake and beneficial effects on wheat PloS One 13(9):e0204408 DOI10.1371/journal.pone.0204408

Nadeem SM, Imran M, Naveed M, Khan MY, Ahmad M, Zahir ZA, Crowley DE. 2017. Synergistic use of biochar, compost and plant growth-promoting rhizobacteria for enhancing cucumber growth under water deficit conditions. Journal of the Science of Food and Agriculture DOI 10.1002/jsfa.8393.

Nakashima K, Ito Y, Yamaguchi-Shinozaki K. 2009. Transcriptional regulatory networks in response to abiotic stresses in Arabidopsis and Grasses. Plant Physiology 149(1):88-95 DOI 10.1104/pp.108.129791. 
598

599

600

601

602

603

604

605

606

607

608

609

610

611

612

613

614

615

616

617

618

619

620

621

622

623

624

625

626

627

628

629

Naqqash T, Hameed S, Imran A, Hanif MK, Majeed A, van Elsas JD. 2016. Differential response of potato toward inoculation with taxonomically diverse plant growth promoting rhizobacteria. Frontiers of Plant Science 7:144 DOI 10.3389/fpls.2016.00144.

Naresh PS, Pramod KP, Sandeep KV. 2014. Morpho-physiological characterization of Indian wheat genotypes and their evaluation under drought condition. African journal of Biotechnology 13(20):2022-2027 DOI 10.5897/ajb2013.13486.

Naureen Z, Rehman NU, Hussain H, Hussain J, Gilani SA, Al Housni SK, Mabood F, Khan AL, Farooq S, Abbas G, Harrasi AA. 2017. Exploring the potentials of Lysinibacillus sphaericus ZA9 for plant growth promotion and biocontrol activities against phytopathogenic fungi. Frontiers in Microbiology 8:1477 DOI 10.3389/fmicb.2017.01477.

Naveed M, Hussain MB, Zahir ZA, Mitter B, Sessitsch A. 2013. Drought stress amelioration in wheat through inoculation with Burkholderia phytofirmans strain PsJN. Plant Growth Regulation 73(2):121-131 DOI 10.1007/s10725-013-9874-8.

Niu XG, Song LC, Xiao YN, and Ge WD. 2018. Drought-tolerant plant growth-promoting rhizobacteria associated with foxtail millet in a semi-arid and their potential in alleviating drought stress. Frontiers in Microbiology 8:11 DOI 10.3389/fmicb.2017.02580

Oteino N, Lally RD, Kiwanuka S, Lloyd A, Ryan D, Germaine KJ, Dowling DN. 2015. Plant growth promotion induced by phosphate solubilizing endophytic Pseudomonas isolates. Frontiers in Microbiology 6:745 DOI 10.3389/fmicb.2015.00745.

Pandey PK, Yadav SK, Singh A, Sarma BK, Mishra A, Singh HB. 2012. Cross-species alleviation of biotic and abiotic stresses by the endophyte Pseudomonas aeruginosa PW09. Journal of Phytopathology 160(10):532-539 DOI 10.1111/j.1439-0434.2012.01941.x.

Percival GC, Fraser GA, Oxenham G. 2003. Foliar salt tolerance of Acer genotypes using chlorophyll fluorescence. Journal of Arboriculture 29(3).

Pujol M, Badosa E, Manceau C, Montesinos E. 2006. Assessment of the environmental fate of the biological control agent of fire blight, Pseudomonas fluorescens EPS62e, on apple by culture and real-time PCR methods. Applied and Environmental Microbiology 72(4):24212427 DOI 10.1128/AEM.72.4.2421-2427.2006.

Qi PF, Johnston A, Balcerzak M, Rocheleau H, Harris LJ, Long XY, Wei YM, Zheng YL, Ouellet T. 2012. Effect of salicylic acid on Fusarium graminearum, the major causal agent of fusarium head blight in wheat. Fungal Biology 116(3):413-426 DOI 10.1016/j.funbio.2012.01.001. 
630 Rajkumar M, Ae N, Prasad MNV, Freitas H. 2010. Potential of siderophore-producing bacteria

631

632

633

634

635

636

637

638

639

640

641

642

643

644

645

646

647

648

649

650

651

652

653

654

655

656

657

658

659

660

661 for improving heavy metal phytoextraction. Trends in Biotechnol 28:142-149 DOI 10.1016/j.tibtech.2009.12.002.

Rehman A, Ahmad R, Safdar M. 2011. Effect of hydrogel on the performance of aerobic rice sown under different techniques. Plant Soil and Environment 57(7):321-325.

Saif S, and Khan MS. 2018. Assessment of toxic impact of metals on proline, antioxidant enzymes, and biological characteristics of Pseudomonas aeruginosa inoculated Cicer arietinum grown in chromium and nickel-stressed sandy clay loam soils. Environmental Monitoring and Assessment 190 DOI 10.1007/s10661-018-6652-0

Sandhya V, Ali SZ, Venkateswarlu B, Reddy G, and Grover M. 2010. Effect of osmotic stress on plant growth promoting Pseudomonas spp. Archives of Microbiology 192:867-876 DOI 10.1007/s00203-010-0613-5

Savazzini F, Longa CM, Pertot I, Gessler C. 2008. Real-time PCR for detection and quantification of the biocontrol agent Trichoderma atroviride strain SC1 in soil. Journal of Microbiological Methods 73(2):185-194 DOI 10.1016/j.mimet.2008.02.004.

Schinner F, Ohlinger R, Kandeler E, Margesin R. 1996. Mtthods in soil biology. Berlin: Springer-Verlag.

Shakeel M, Rais A, Hassan MN, Hafeez FY. 2015. Root associated Bacillus sp. improves growth, yield and zinc translocation for basmati rice (Oryza sativa) varieties. Frontiers in Microbiology 6:1286 DOI 10.3389/fmicb.2015.01286.

Sharma A, Gontia I, Agarwal PK, Jha B. 2010. Accumulation of heavy metals and its biochemical responses inSalicornia brachiata, an extreme halophyte. Marine Biology Research 6(5):511-518 DOI 10.1080/17451000903434064.

Sharma S, Kulkarni J, Jha B. 2016. Halotolerant rhizobacteria promote growth and enhance salinity tolerance in peanut. Frontiers in Microbiology 7:1600 DOI 10.3389/fmicb.2016.01600.

Shukla PS, Agarwal PK, Jha B. 2012. Improved salinity tolerance of Arachis hypogaea (L.) by the interaction of halotolerant plant-growth-promoting rhizobacteria. Journal of Plant Growth Regulation 31(2):195-206 DOI 10.1007/s00344-011-9231-y.

Siddikee MA, ereen MIZ, LI C, Dai C. 2016. Endophytic fungus Phomopsis liquidambari and different doses of $\mathrm{N}$-fertilizer alter microbial community structure and function in rhizosphere of rice. Scientific Reports 6:32270 DOI 0.1038/srep32270. 
662

663

664

665

666

667

668

669

670

671

672

673

674

675

676

677

678

679

680

681

682

683

684

685

686

687

688

689

690

691

692

693

Simonsen AK, Han S, Rekret P, Rentschler CS, Heath KD, Stinchcombe JR. 2015. Short-term fertilizer application alters phenotypic traits of symbiotic nitrogen fixing bacteria. PeerJ 3:e1291 DOI 10.7717/peerj.1291.

Sleimi N, Bankaji I, Touchan H, Corbineau F. 2013. Effects of temperature and water stresses on germination of some varieties of chickpea (Cicer arietinum). African Journal of Biotechnology 12:2201-2206

Sojka RE, Entry JA, Fuhrmann JJ. 2006. The influence of high application rates of polyacrylamide on microbial metabolic potential in an agricultural soil. Applied Soil Ecology 32(2):243-252 DOI 10.1016/j.apsoil.2005.06.007.

Su LQ, Li JG, Xue H, Wang XF. 2017. Super absorbent polymer seed coatings promote seed germination and seedling growth of Caragana korshinskii in drought. Journal of Zhejiang University Science B (Biomedicine \& Biotechnology) 18(8):696-706 DOI 10.1631/jzus.B1600350.

Sudisha J, Niranjana SR, Sukanya SL, Girijamba R, Lakshmi Devi N, Shekar Shetty H. 2010. Relative efficacy of strobilurin formulations in the control of downy mildew of sunflower. Journal of Pest Science 83(4):461-470 DOI 10.1007/s10340-010-0316-3.

Tabatabai M, Bremner J. 1969. Use of p-nitrophenyl phosphate for assay of soil phosphatase activity. Soil Biology and Biochemistry 1(4):201-207 DOI 10.1016/0038-0717(69)90012-1.

Terry, Richard E, Nelson, Sheldon D. 1986. Efficts of polyacrylamide and irrigation method on soil physical properties. Soil Science 141(5):317-320 DOI 10.1007/bf00008338.

Tiwari S, Lata C, Chauhan PS, Nautiyal CS. 2016. Pseudomonas putida attunes morphophysiological, biochemical and molecular responses in Cicer arietinum L. during drought stress and recovery. Plant Physiology and Biochemistry 99:108-117 DOI 10.1016/j.plaphy.2015.11.001.

Tripti, Kumar A, Usmani Z, Kumar V, Anshumali. 2017. Biochar and flyash inoculated with plant growth promoting rhizobacteria act as potential biofertilizer for luxuriant growth and yield of tomato plant. Journal of Environmental Management 190:20-27 DOI 10.1016/j.jenvman.2016.11.060.

Vrieze MD, Pandey P, Bucheli TD, Varadarajan AR, Ahrens CH, Weisskopf L, Bailly A. 2015. Volatile organic compounds from native potato-associated Pseudomonasas potential anti-oomycete agents. Frontiers in Microbiology 6(e1003311) DOI 10.3389/fmicb.2015.01295. 
694 Wan H, Zhao Z, Qian C, Sui Y, Malik AA, Chen J. 2010. Selection of appropriate reference

695

696

697

698

699

700

701

702

703

704

705

706

707

708

709

710

711

712

713

714

715

716

717

718

719

720

721

722

723

724

725 genes for gene expression studies by quantitative real-time polymerase chain reaction in cucumber. Analytical Biochemistry 399(2):257-261 DOI 10.1016/j.ab.2009.12.008.

Wang HW, Dai CC, Zhu H, Wang XX. 2014. Survival of a novel endophytic fungus Phomopsis liquidambari $\mathrm{B} 3$ in the indole-contaminated soil detected by real-time PCR and its effects on the indigenous microbial community. Microbiology Research 169(12):881-887 DOI 10.1016/j.micres.2014.05.006.

Wang LY, Li J, Li QX, Chen SF. 2013. Paenibacillus beijingensis sp. nov., a nitrogen-fixing species isolated from wheat rhizosphere soil. Antonie Van Leeuwenhoek 104(5):675-683 DOI 10.1007/s10482-013-9974-5.

Wang Z, Xu G, Ma P, Lin Y, Yang X, Cao C. 2017. Isolation and characterization of a phosphorus-solubilizing bacterium from rhizosphere soils and its colonization of chinese cabbage (Brassica campestris ssp. chinensis). Frontiers in Microbiology 8:1270 DOI 10.3389/fmicb.2017.01270.

Webb J, Harrison R, Ellis S. 2000. Nitrogen fluxes in three arablesoils in the UK. European Journal of Agronomy 13:207-223.

Wei L, Deng X-G, Zhu T, Zheng T, Li P-X, Wu J-Q, Zhang D-W, Lin H-H. 2015. Ethylene is involved in brassinosteroids induced alternative respiratory pathway in cucumber (Cucumis sativus L.) seedlings response to abiotic stress. Frontiers in Plant Science 6(982) DOI 10.3389/fpls.2015.00982.

Wu YR, Deng ZY, Lai JB, Zhang YY, Yang CP, Yin BJ, Zhao QZ, Zhang L, Li Y, Yang CW, Xie Q. 2009. Dual function of Arabidopsis ATAF1 in abiotic and biotic stress responses. Cell Research 19(11):1279-1290 DOI 10.1038/cr.2009.108.

Xun F, Xie B, Liu S, Guo C. 2015. Effect of plant growth-promoting bacteria (PGPR) and arbuscular mycorrhizal fungi (AMF) inoculation on oats in saline-alkali soil contaminated by petroleum to enhance phytoremediation. Environmental Science \& Pollution Research 22(1):598-608 DOI 10.1007/s11356-014-3396-4.

Yang B, Wang X-M, Ma H-Y, Jia Y, Li X, Dai C-C. 2013. Effects of the fungal endophyte Phomopsis liquidambari on nitrogen uptake and metabolism in rice. Plant Growth Regulation 73(2):165-179 DOI 10.1007/s10725-013-9878-4.

Yang J, Kloepper JW, Ryu CM. 2009. Rhizosphere bacteria help plants tolerate abiotic stress. Trends in Plant Science 14(1):1-4 DOI 10.1016/j.tplants.2008.10.004. 
726

727

728

729

730

731

732

733

734

735

736

737

738

739

740

741
Zhang J, Liu J, Meng L, Ma Z, Tang X, Cao Y, Sun L. 2012. Isolation and characterization of plant growth-promoting rhizobacteria from wheat roots by wheat germ agglutinin labeled with fluorescein isothiocyanate. Journal of Microbiology 50(2):191-198 DOI $10.1007 / \mathrm{s} 12275-012-1472-3$.

Zhang XM, Yu HJ, Sun C, Deng J, Zhang X, Liu P, Li YY, Li Q, Jiang WJ. 2017. Genomewide characterization and expression profiling of the NAC genes under abiotic stresses in Cucumis sativus. Plant Physiology and Biochemistry 113(98-109 DOI 10.1016/j.plaphy.2017.01.023.

Zhou Y, He P, Xu Y, Liu Q, Yang Y, Liu S. 2017. Overexpression of CsLEA1 1, a Y3SK2-type dehydrin gene from cucumber (Cucumis sativus), enhances tolerance to heat and cold in Escherichia coli. Amb Express 7 DOI 10.1186/s13568-017-0483-1.

Zhu X, Qi L, Liu X, Cai S, Xu H, Huang R, Li J, Wei X, Zhang Z. 2014. The wheat ethylene response factor transcription factor pathogen-induced $E R F 1$ mediates host responses to both the necrotrophic pathogen rhizoctonia cerealis and freezing stresses. Plant Physiology 164(3):1499-1514. 


\section{Figure 1}

Effects of super absorbent polymer supply on shoot length $(A)$, root length $(B)$, shoot fresh weight $(C)$, root fresh weight (D), shoot dry weight $(E)$ and root dry weight $(F)$ of wheat and cucumber seedlings.

Values are given as mean of three independent biological replicates, and bearing different letters $(a, b, c)$ are significantly different from each other according to the least significant difference (LSD) test $(p<0.05)$. The bars represent the standard error. SAP: Super Absorbent Polymer, BJ-18: P. beijingensis strain BJ-18, L-56: Bacillus sp. strain L-56. 
A

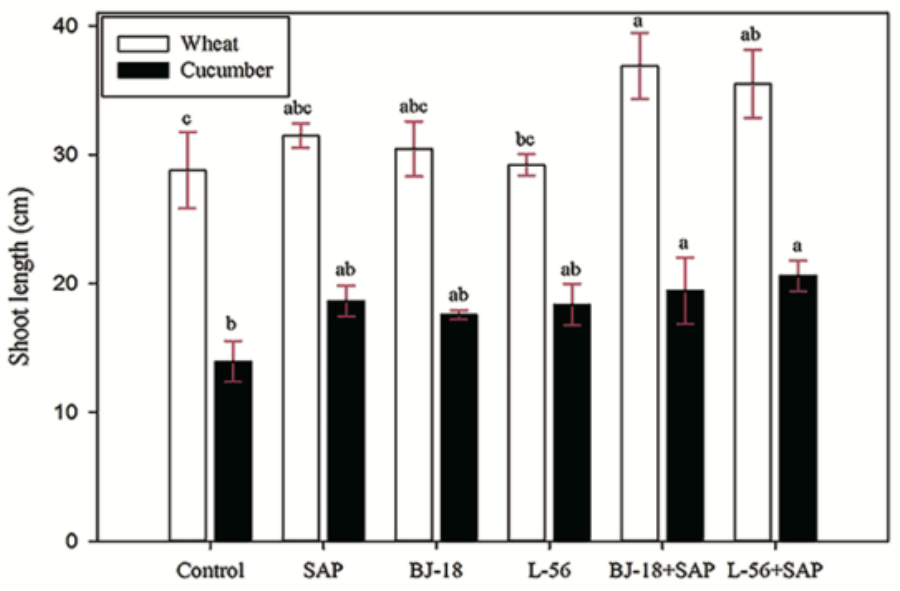

$\mathrm{C}$
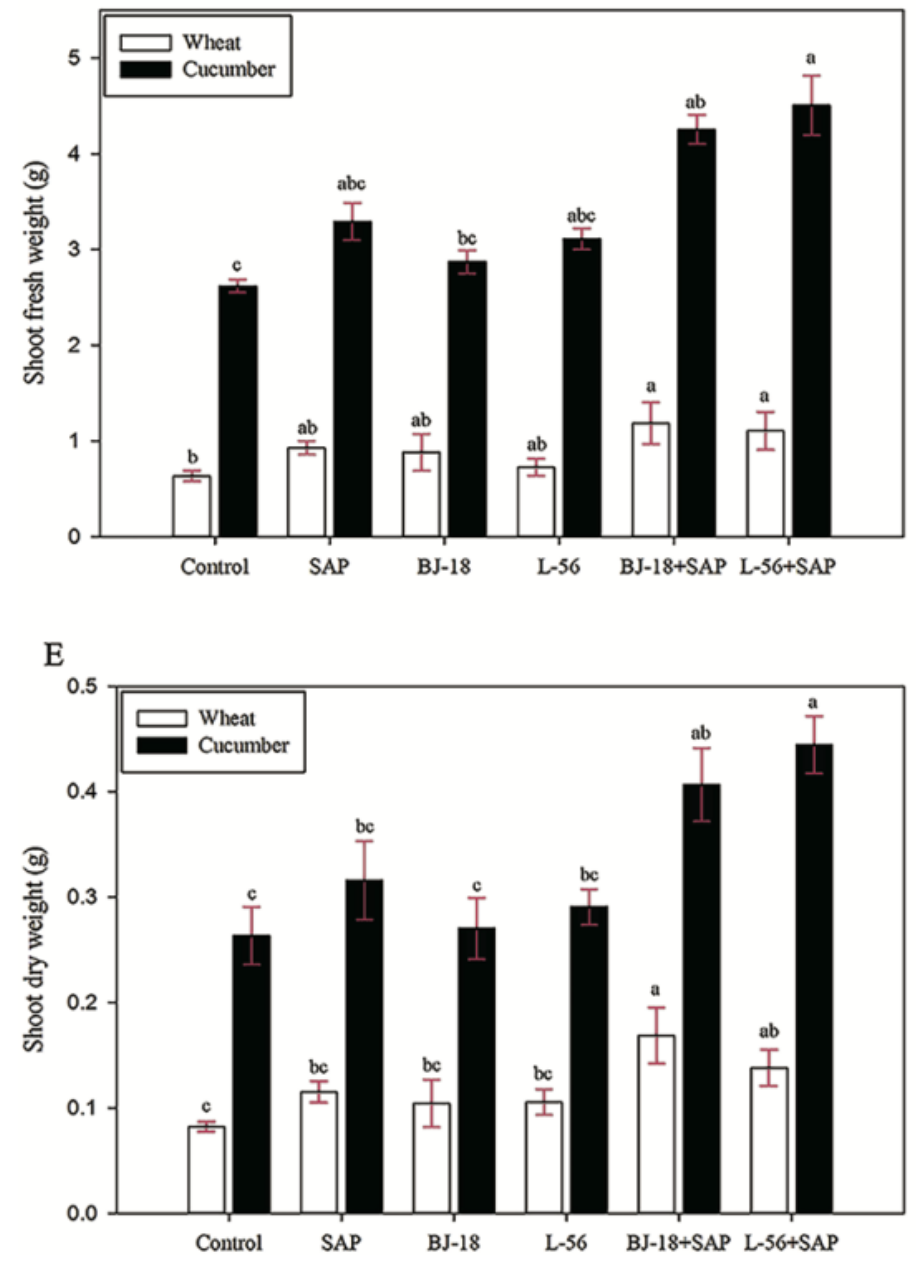

B

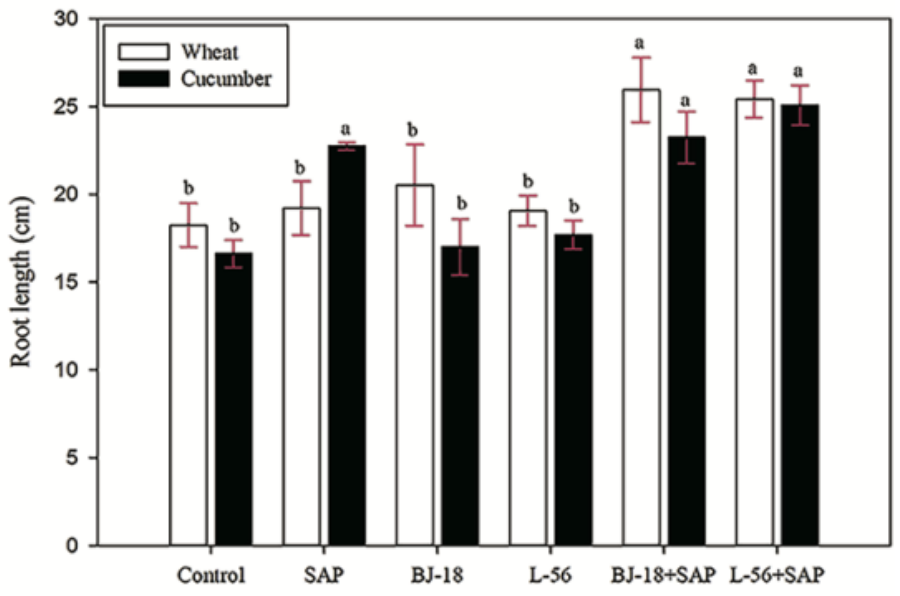

$\mathrm{D}$

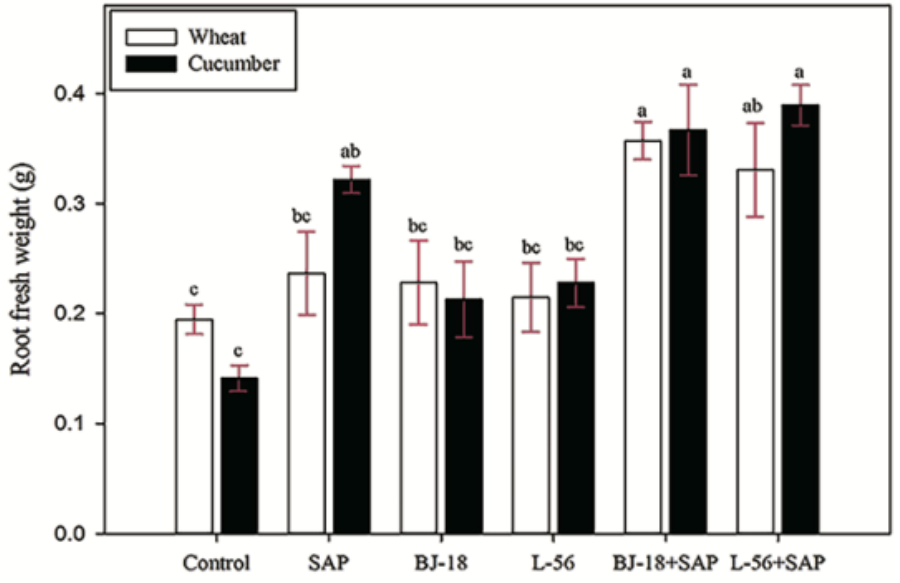

F

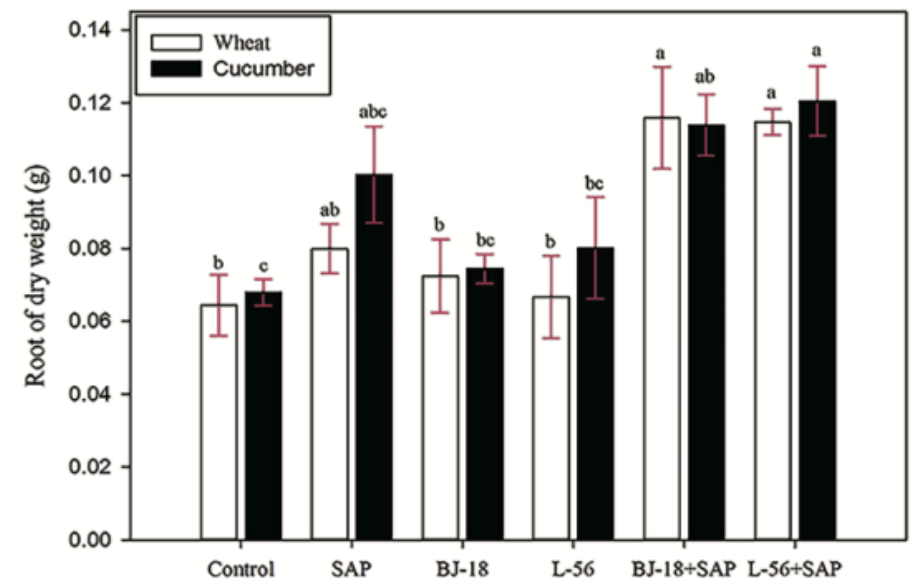


Figure 2

Effects of super absorbent polymer supply on proline concentration (A), total soluble sugar concentration (B), chlorophyll content (C) of wheat and cucumber seedlings.

Values are given as mean of three independent biological replicates, and bearing different letters $(a, b, c)$ are significantly different from each other according to the least significant difference (LSD) test $(p<0.05)$. The bars represent the standard error. SAP: Super Absorbent Polymer, BJ-18: P. beijingensis strain BJ-18, L-56: Bacillus sp. strain L-56.

A

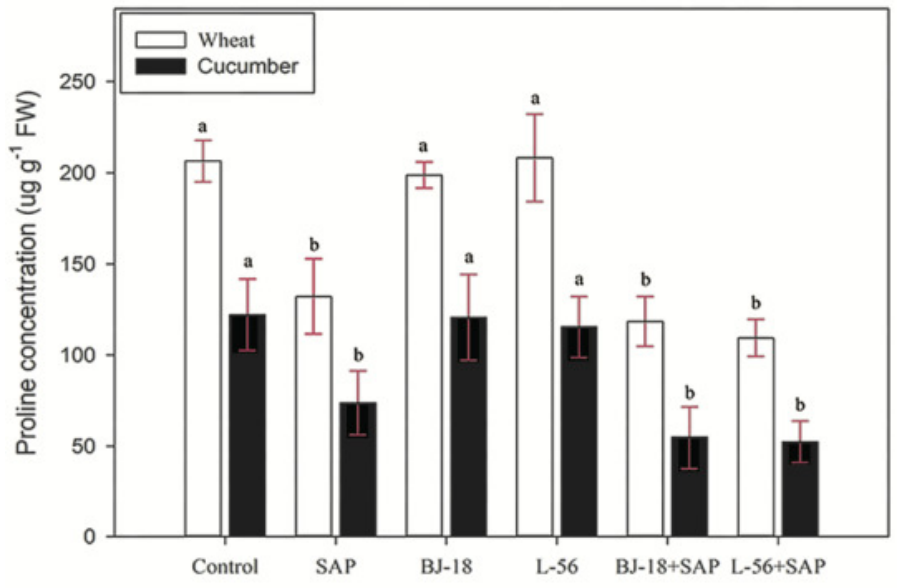

B

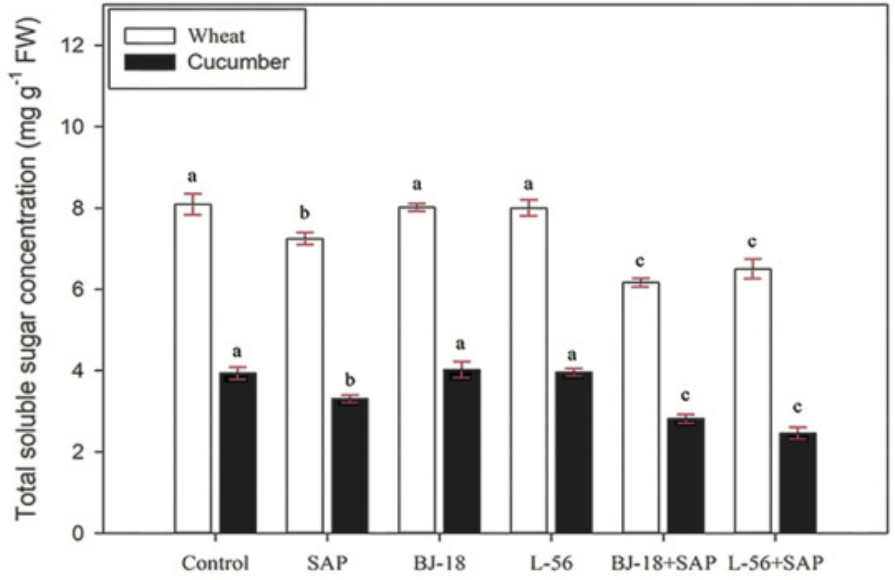

C

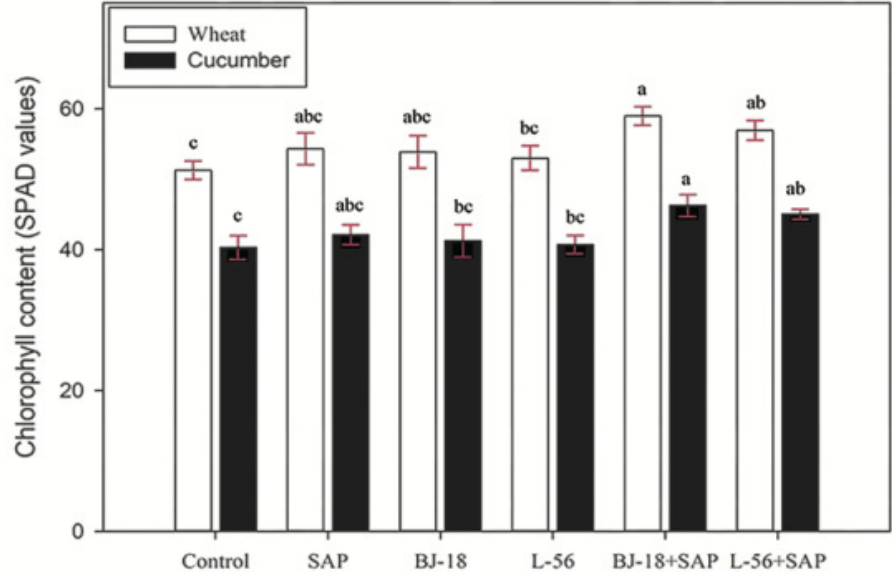




\section{Figure 3}

Effects of super absorbent polymer supply on enzyme activities of urease (A), sucrose (B), alkaline phosphatase (C), acid phosphatase (D) and dehydrogenase (E) of rhizosphere soil.

The values are given as mean of three independent biological replicates, and bearing different letters $(a, b, c)$ are significantly different from each other according to the LSD test $(p<0.05)$. The bars represent the standard error. SAP: Super Absorbent Polymer, BJ-18: $P$. beijingensis strain BJ-18, L-56: Bacillus sp. strain L-56, pNP: p-Nitrophenol, TPF: Triphenylformazan. 
A
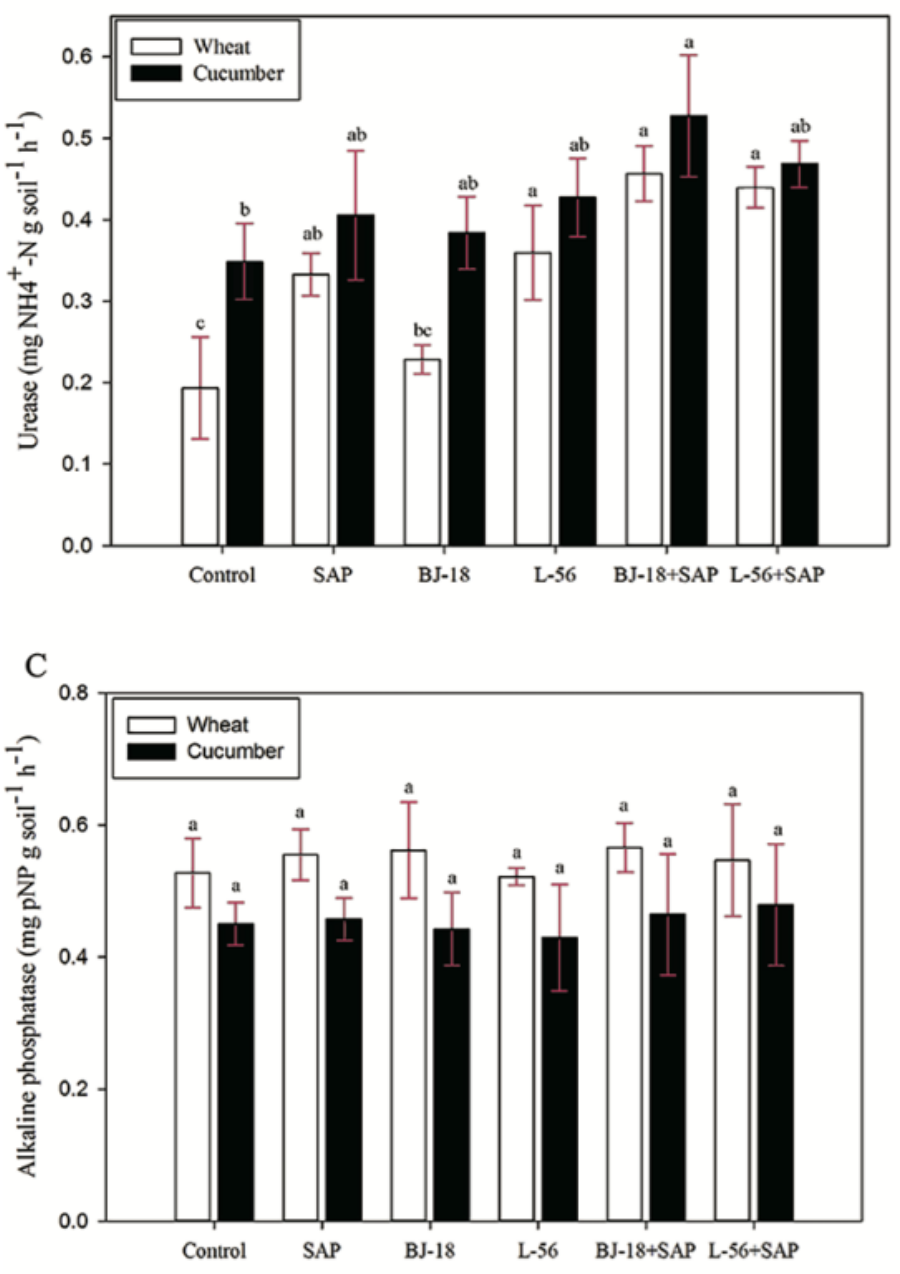

B

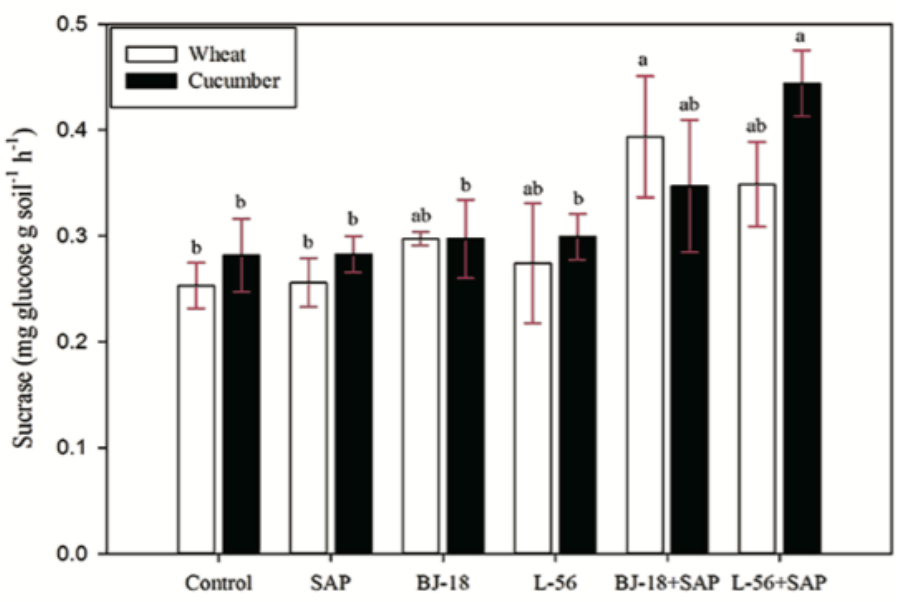

D

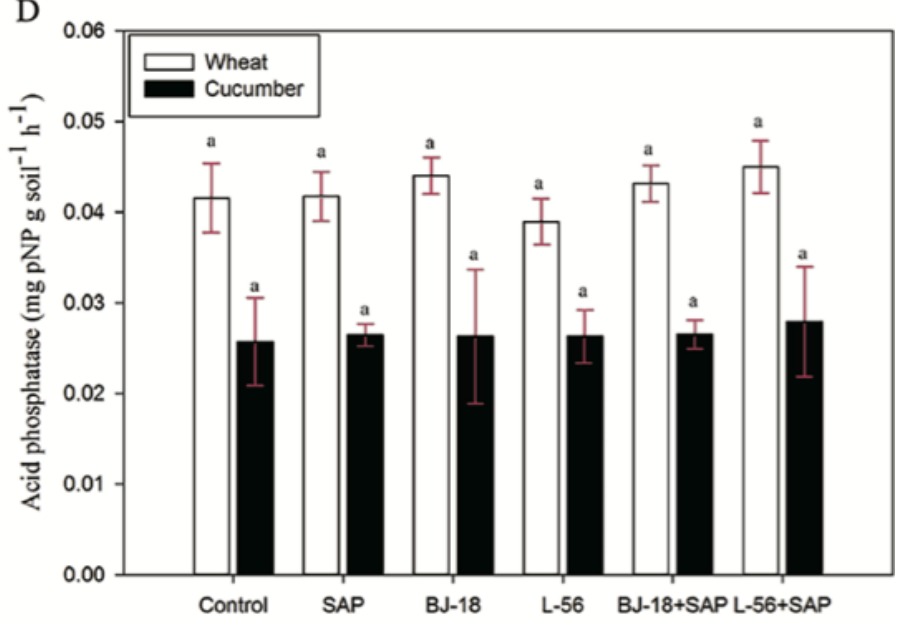

E

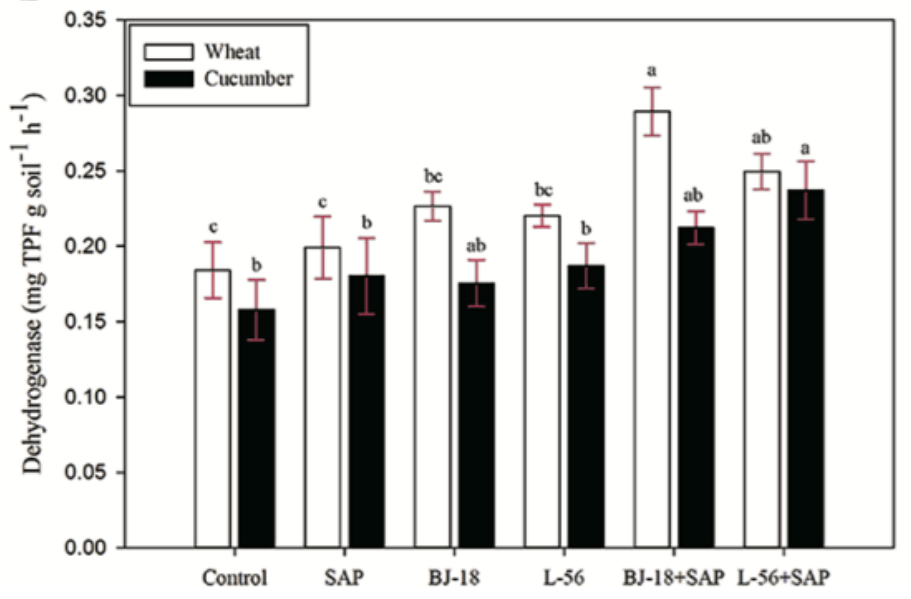




\section{Figure 4}

Effects of super absorbent polymer supply on relative gene expression level of stressgenes in wheat and cucumber seedlings.

The values are given as mean of three independent biological replicates, and bearing different letters $(a, b, c)$ are significantly different from each other according to the least significant difference (LSD) test $(p<0.05)$. The bars represent the standard error. SAP: Super Absorbent Polymer, BJ-18: P. beijingensis strain BJ-18, L-56: Bacillus sp. strain L-56.. a: DHN for wheat, ACS for cucumber. 
A

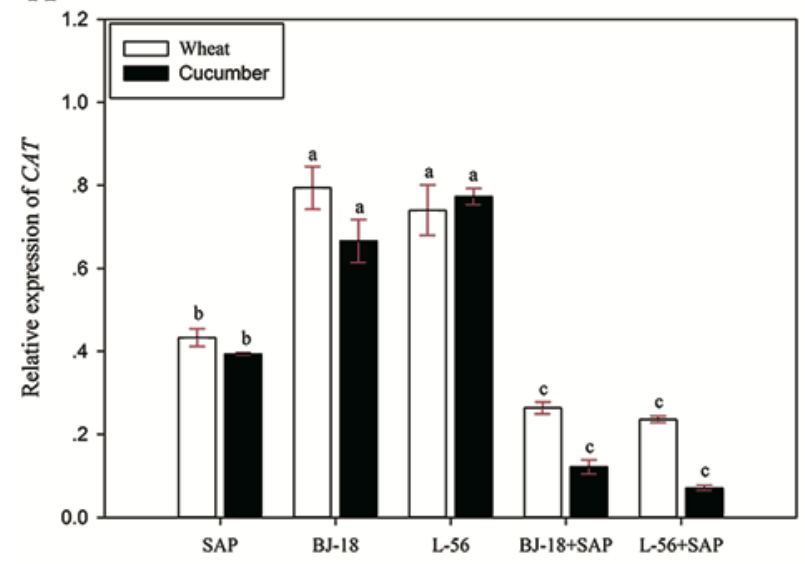

C

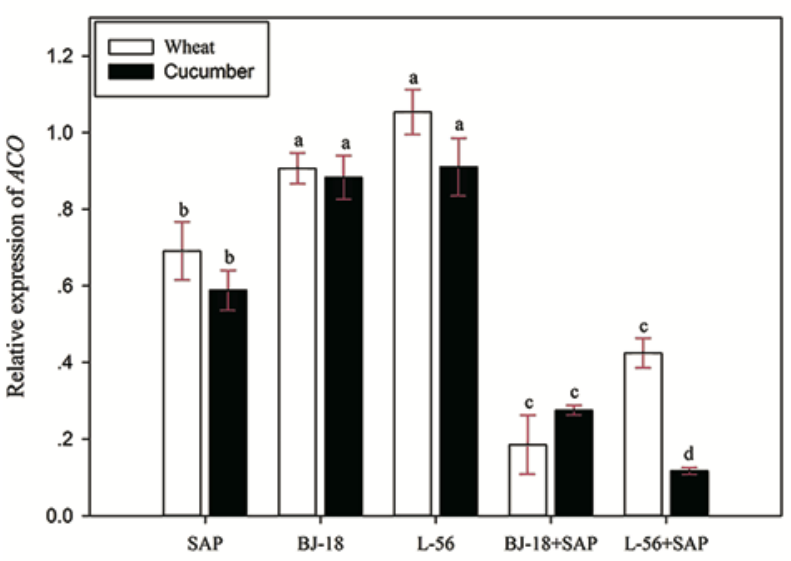

E

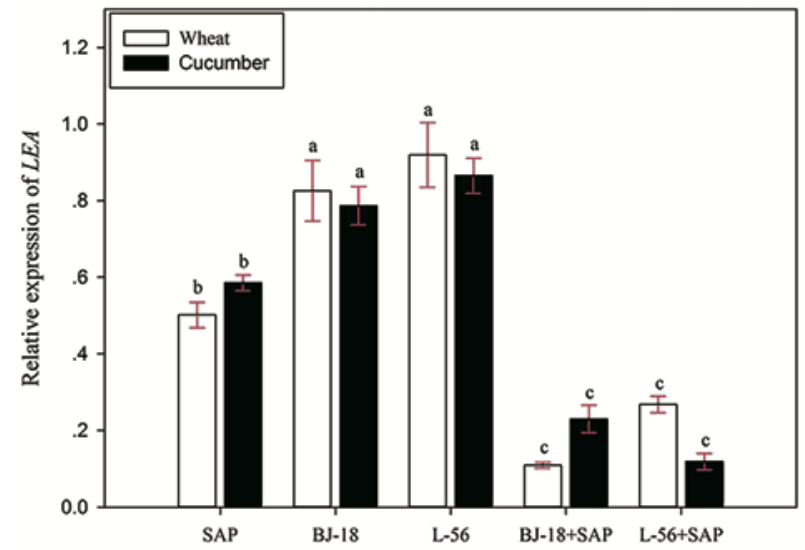

B

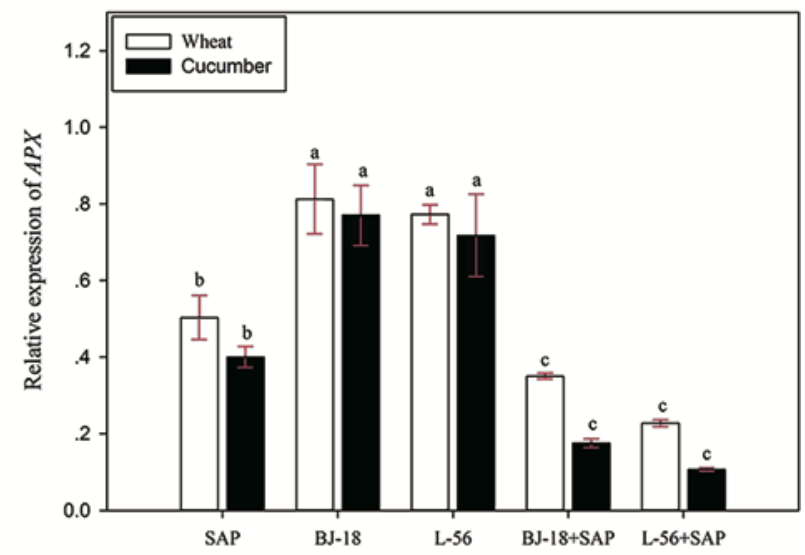

D

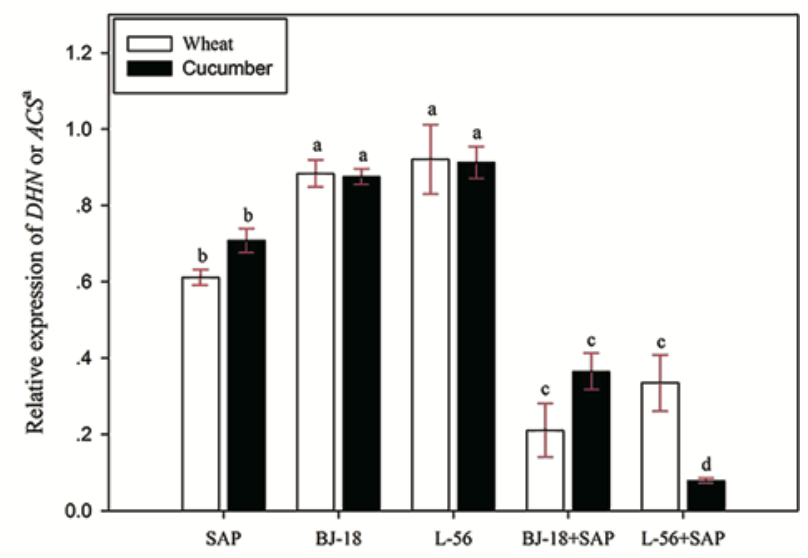

F

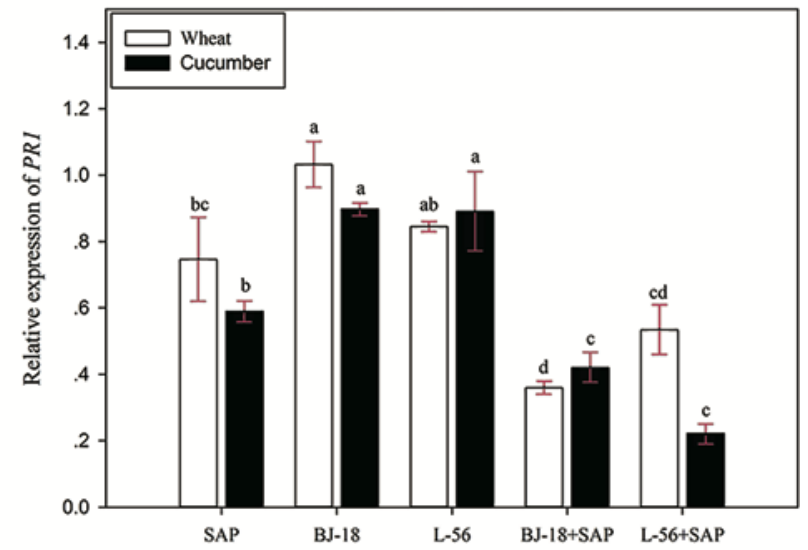

G 


\section{Table 1 (on next page)}

Bacterial cultures and genomes used in this study. 
1 Table 1 Bacterial cultures and genomes used in this study.

\begin{tabular}{cccc}
\hline Strain No. & Original Source & ID & References/Accession No. \\
\hline BJ-18 & $\begin{array}{c}\text { Wheat (rhizosphere } \\
\text { isolate), China. }\end{array}$ & $\begin{array}{c}\text { Paenibacillus } \\
\text { beijingensis }\end{array}$ & (Wang et al., 2013) \\
L-56 & $\begin{array}{c}\text { Maize (rhizosphere } \\
\text { isolate), China }\end{array}$ & Bacillus sp. & MF988362 \\
\hline
\end{tabular}


Table 2 (on next page)

Description of treatments used for pot experiment. 
1 Table 2 Description of treatments used for pot experiment.

\begin{tabular}{ll}
\hline Treatments & Description \\
\hline Control & Rice hull powder without biofertilizer and SAP \\
SAP & Rice hull powder + SAP $(100: 1, \mathrm{w} / \mathrm{w})$ \\
BJ-18 & Biofertilizer of P. beijingensis BJ-18 \\
L-56 & Biofertilizer of Bacillus sp. L-56 \\
BJ-18+SAP & Biofertilizer of $P$. beijingensis BJ-18 + SAP $(100: 1, \mathrm{w} / \mathrm{w})$ \\
L-56+SAP & Biofertilizer of Bacillus sp. L-56 + SAP $(100: 1, \mathrm{w} / \mathrm{w})$ \\
\hline
\end{tabular}

2 
Table 3(on next page)

Primers sequence and accession number in NCBI. 
1 Table 3 Primers sequence and accession number in NCBI.

\begin{tabular}{|c|c|c|c|}
\hline Primer & Primer sequence $5^{\prime}-3^{\prime}$ & NCBI Accession No. & Reference \\
\hline$n i f B$ & $\begin{array}{l}\text { GAAGGTGAGAGTGAGGATGG } \\
\text { TTGCTTCAGGCTCATCTCC }\end{array}$ & MH202771 & This study \\
\hline amye & $\begin{array}{l}\text { СTTCTCGTTCAGGCAGTAC } \\
\text { TATTGACCGCAGTGATAGC }\end{array}$ & MH202772 & This study \\
\hline$T a C A T$ & $\begin{array}{l}\text { CCATCTGGCTCTCCTACTGG } \\
\text { AGAACTTGGACGACGGCCCTGA }\end{array}$ & E16461 & (Moloudi et al., 2013) \\
\hline$C s C A T$ & $\begin{array}{l}\text { TTCGGCGTACAAGCATATTCC } \\
\text { GTGGCGTGACTGTGATTCG }\end{array}$ & AY274258 & This study \\
\hline$T a A P X$ & $\begin{array}{l}\text { CACCACATCTAAGGGACATC } \\
\text { TTCAGAGGGTCACGAGTC }\end{array}$ & EF555121 & This study \\
\hline$C s A P X$ & $\begin{array}{l}\text { ATGATTGTTGACTTGTTATGTG } \\
\text { GATGAGGCAGAACGAACC }\end{array}$ & EU798448 & This study \\
\hline $\operatorname{TaNAC} 2 D$ & $\begin{array}{l}\text { ACCTCAGCTACGACGACATCCAG } \\
\text { GCGGCGAAGAAGTCATCCGTTCC }\end{array}$ & GQ231954.1 & (Huang and Wang, 2016) \\
\hline CsNAC22 & $\begin{array}{l}\text { GACCTCGGTCTCGTCTGAAG } \\
\text { CTACAATGTTGTTGGACTTCGG }\end{array}$ & --- & (Zhang et al., 2017) \\
\hline TaLEA & $\begin{array}{l}\text { AGATCGACGGTGACGTGAAG } \\
\text { GTCCATGATCTTGCCCAGTAG }\end{array}$ & --- & (Li et al., 2018) \\
\hline CsLEA11 & $\begin{array}{l}\text { CGAGCAGTTCCAGCTCTA } \\
\text { CTTCCGGTTAACTTCTCCTT }\end{array}$ & --- & (Zhou et al., 2017) \\
\hline TaACO2 & $\begin{array}{l}\text { GAGGAACGAGGGCGAGGAG } \\
\text { TCAGTTATCAGGCGGTGGC }\end{array}$ & --- & (Zhu et al., 2014) \\
\hline CsACO1 & $\begin{array}{l}\text { ACCTTCTTCTTACGCCATC } \\
\text { GCCACCTACCTTGTCATC }\end{array}$ & AB006806 & (Wei et al., 2015) \\
\hline CsACS1 & $\begin{array}{l}\text { CTTCAGGCGTTATTCAGATG } \\
\text { GTGCTCGTGTTCTCCATT }\end{array}$ & U59813.1 & (Wei et al., 2015) \\
\hline TaDHN3 & $\begin{array}{l}\text { TGGGACGGGCTCAGTGCT } \\
\text { ATGGGCGGGAGGAGGAAG }\end{array}$ & --- & (Zhu et al., 2014) \\
\hline TaPR1-1a & $\begin{array}{l}\text { TTCATCATCTGCAGCTACAACC } \\
\text { CGGTACATATATACAGCCGGTCTAA }\end{array}$ & --- & (Qi et al., 2012) \\
\hline CsPRI-1a & $\begin{array}{l}\text { AACTCTGGCGGACCTTAC } \\
\text { TCAATATGGCCTTTGGTATAAG }\end{array}$ & DQ641122 & (Dong et al., 2014) \\
\hline TaACTIN & $\begin{array}{l}\text { GTCGGTGAAGGGGACTTACA } \\
\text { TTCATACAGCAGGCAAGCAC }\end{array}$ & AB181991.1 & (Huang and Wang, 2016) \\
\hline CsACTIN & $\begin{array}{l}\text { AGAGATGGCTGGAATAGAAC } \\
\text { CTGGTGATGGTGTGAGTC }\end{array}$ & DQ115883 & (Wan et al., 2010) \\
\hline
\end{tabular}




\section{Table 4 (on next page)}

Effects of super absorbent polymer supply on germination of wheat and cucumber seeds.

Values are given as mean $\pm \mathrm{SE}$ of three independent biological replicates, and bearing

different letters (a, b, c) at one specific time (e.g. 5 or 6 days) are significantly different from each other according to the least significant difference (LSD) test $(p<0.05)$; $D$ : days. 
1 Table 4 Effects of super absorbent polymer supply on germination of wheat and cucumber seeds.

\begin{tabular}{|c|c|c|c|c|c|c|c|c|c|c|c|}
\hline \multirow{2}{*}{ Plant } & \multirow{2}{*}{ Treatments } & \multicolumn{10}{|c|}{ Seed germination (\%) at different day } \\
\hline & & $5 \mathrm{D}$ & $6 \mathrm{D}$ & $7 \mathrm{D}$ & $8 \mathrm{D}$ & $9 \mathrm{D}$ & $10 \mathrm{D}$ & $11 \mathrm{D}$ & $12 \mathrm{D}$ & $13 \mathrm{D}$ & $14 \mathrm{D}$ \\
\hline \multirow{6}{*}{ Wheat } & Control & $0^{\mathrm{a}}$ & $0^{\mathrm{a}}$ & $0^{\mathrm{b}}$ & $0^{\mathrm{c}}$ & $0^{\mathrm{d}}$ & $0^{\mathrm{c}}$ & $6.3 \pm 1.2^{\mathrm{d}}$ & $9.7 \pm 0.3^{\mathrm{d}}$ & $18.0 \pm 1.0^{\mathrm{e}}$ & $22.7 \pm 1.3^{\mathrm{e}}$ \\
\hline & SAP & $0^{\mathrm{a}}$ & $0^{\mathrm{a}}$ & $0^{\mathrm{b}}$ & $0^{\mathrm{c}}$ & $5.7 \pm 1.2^{\mathrm{c}}$ & $12.3 \pm 0.9^{\mathrm{b}}$ & $24.3 \pm 1.5^{\mathrm{b}}$ & $37.7 \pm 1.8^{\mathrm{b}}$ & $48.0 \pm 2.3^{\mathrm{c}}$ & $52.3 \pm 3.0^{\mathrm{c}}$ \\
\hline & BJ-18 & $0^{\mathrm{a}}$ & $0^{\mathrm{a}}$ & $0^{\mathrm{b}}$ & $0^{\mathrm{c}}$ & $0^{\mathrm{d}}$ & $1.0 \pm 1.0^{\mathrm{c}}$ & $7.7 \pm 0.7^{\mathrm{c}}$ & $17.7 \pm 1.2^{\mathrm{c}}$ & $29.0 \pm 1.2^{\mathrm{d}}$ & $33.0 \pm 0.6^{\mathrm{d}}$ \\
\hline & L-56 & $0^{\mathrm{a}}$ & $0^{\mathrm{a}}$ & $0^{\mathrm{b}}$ & $0^{\mathrm{c}}$ & $0^{\mathrm{d}}$ & $1.0 \pm 1.0^{\mathrm{c}}$ & $7.7 \pm 0.7^{\mathrm{cd}}$ & $13.0 \pm 1.7^{\mathrm{cd}}$ & $22.7 \pm 1.4^{\mathrm{de}}$ & $29.7 \pm 1.3^{\mathrm{d}}$ \\
\hline & BJ-18 +SAP & $0^{\mathrm{a}}$ & $0^{\mathrm{a}}$ & $8.7 \pm 1.3^{\mathrm{a}}$ & $14.7 \pm 2.1^{\mathrm{a}}$ & $20.3 \pm 2.0^{\mathrm{b}}$ & $46.0 \pm 2.5^{\mathrm{a}}$ & $50.7 \pm 1.8^{\mathrm{a}}$ & $56.3 \pm 2.3^{\mathrm{a}}$ & $67.7 \pm 1.8^{\mathrm{a}}$ & $70.0 \pm 1.0^{\mathrm{a}}$ \\
\hline & L-56+SAP & $0^{\mathrm{a}}$ & $0^{\mathrm{a}}$ & $6.7 \pm 2.0^{\mathrm{a}}$ & $17.3 \pm 2.5^{\mathrm{b}}$ & $24.7 \pm 1.2^{\mathrm{a}}$ & $44.3 \pm 2.4^{\mathrm{a}}$ & $52.3 \pm 2.2^{\mathrm{a}}$ & $57.7 \pm 7.8^{\mathrm{a}}$ & $60.7 \pm 1.4^{\mathrm{b}}$ & $62.0 \pm 2.1^{b}$ \\
\hline \multirow{6}{*}{ Cucumber } & Control & $0^{\mathrm{a}}$ & $0^{\mathrm{a}}$ & $0^{\mathrm{a}}$ & $0^{\mathrm{b}}$ & $0^{c}$ & $0^{c}$ & $0^{\mathrm{d}}$ & $4.3 \pm 0.8^{c}$ & $6.3 \pm 0.7^{d}$ & $14.3 \pm 0.9^{c}$ \\
\hline & SAP & $0^{\mathrm{a}}$ & $0^{\mathrm{a}}$ & $0^{\mathrm{a}}$ & $0^{\mathrm{b}}$ & $0^{\mathrm{c}}$ & $13.3 \pm 2.0^{\mathrm{b}}$ & $17.3 \pm 2.2^{b}$ & $21.7 \pm 3.9^{b}$ & $31.3 \pm 4.1^{\mathrm{b}}$ & $39.3 \pm 3.3^{b}$ \\
\hline & BJ-18 & $0^{\mathrm{a}}$ & $0^{\mathrm{a}}$ & $0^{\mathrm{a}}$ & $0^{\mathrm{b}}$ & $0^{\mathrm{c}}$ & $1.0 \pm 1.0^{\mathrm{c}}$ & $5.3 \pm 1.2^{\mathrm{c}}$ & $8.7 \pm 1.2^{\mathrm{c}}$ & $12.0 \pm 1.5^{\mathrm{cd}}$ & $19.3 \pm 1.2^{\mathrm{c}}$ \\
\hline & L-56 & $0^{\mathrm{a}}$ & $0^{\mathrm{a}}$ & $0^{\mathrm{a}}$ & $0^{\mathrm{b}}$ & $0^{\mathrm{c}}$ & $0^{\mathrm{c}}$ & $4.3 \pm 0.9^{\mathrm{cd}}$ & $7.3 \pm 2.0^{c}$ & $13.7 \pm 1.2^{\mathrm{c}}$ & $20.3 \pm 1.3^{c}$ \\
\hline & BJ-18 +SAP & $0^{\mathrm{a}}$ & $0^{\mathrm{a}}$ & $0^{\mathrm{a}}$ & $8.3 \pm 2.1^{\mathrm{a}}$ & $10.0 \pm 1.0^{\mathrm{b}}$ & $27.7 \pm 3.8^{\mathrm{a}}$ & $35.0 \pm 1.5^{\mathrm{a}}$ & $37.7 \pm 2.2^{\mathrm{a}}$ & $44.7 \pm 2.0^{\mathrm{a}}$ & $51.3 \pm 1.8^{\mathrm{a}}$ \\
\hline & L-56+SAP & $0^{\mathrm{a}}$ & $0^{\mathrm{a}}$ & $0^{\mathrm{a}}$ & $8.3 \pm 3.1^{\mathrm{a}}$ & $13.0 \pm 1.0^{\mathrm{a}}$ & $24.3 \pm 2.3^{\mathrm{a}}$ & $32.7 \pm 2.0^{\mathrm{a}}$ & $41.7 \pm 2.6^{\mathrm{a}}$ & $49.7 \pm 2.8^{\mathrm{a}}$ & $56.0 \pm 3.2^{\mathrm{a}}$ \\
\hline
\end{tabular}


3 Values are given as mean $\pm \mathrm{SE}$ of three independent biological replicates, and bearing different letters (a, b, c) at one specific time (e.g. 45 or 6 day) are significantly different from each other according to the least significant difference (LSD) test (p<0.05), D: day, SAP:

5 Super Absorbent Polymer, BJ-18: P. beijingensis strain BJ-18, L-56: Bacillus sp. Strain L-56. 


\section{Table 5 (on next page)}

Survival of different bacterial strains inoculated to plants (wheat and cucumber) and population dynamics in the rhizosphere after thinning.

Values are given as mean \pm SE of three independent biological replicates, and bearing

different letters (a, b, c) at one specific time (e.g. 14 or 19 days) are significantly different from each other according to the LSD test $(p<0.05)$; $D$ : days; ND: not detected. 
Table 5 Survival of different bacterial strains inoculated to wheat and cucumber and population dynamics in the rhizosphere after thinning.

\begin{tabular}{|c|c|c|c|c|c|c|c|c|}
\hline \multirow{2}{*}{ Plant } & \multirow{2}{*}{ Treatment } & \multicolumn{7}{|c|}{ Inoculant concentration in the rhizospher (copies $\mathrm{ng}^{-1} \mathrm{gDNA}$ ) } \\
\hline & & $14 \mathrm{D}$ & $19 \mathrm{D}$ & $24 \mathrm{D}$ & $29 \mathrm{D}$ & $34 \mathrm{D}$ & $39 \mathrm{D}$ & $44 \mathrm{D}$ \\
\hline & S & & & & & & & \\
\hline \multirow{4}{*}{ Wheat } & BJ-18 & $123.9 \pm 8.1^{\mathrm{b}}$ & $142.0 \pm 4.0^{\mathrm{d}}$ & $140.0 \pm 1.0^{\mathrm{d}}$ & $124.2 \pm 3.9^{\mathrm{d}}$ & $96.1 \pm 3.2^{\mathrm{c}}$ & $37.1 \pm 1.6^{\mathrm{c}}$ & $19.3 \pm 0.2^{b}$ \\
\hline & L-56 & $198.9 \pm 20.0^{\mathrm{a}}$ & $214.5 \pm 0.9^{b}$ & $200.2 \pm 1.4^{b}$ & $180.7 \pm 5.8^{\mathrm{b}}$ & $130.3 \pm 1.4^{\mathrm{b}}$ & $48.6 \pm 3.7^{\mathrm{c}}$ & $17.2 \pm 0.2^{\mathrm{b}}$ \\
\hline & BJ-18 +SAP & $121.2 \pm 1.6^{\mathrm{b}}$ & $157.7 \pm 3.7^{\mathrm{c}}$ & $173.1 \pm 3.2^{\mathrm{c}}$ & $264.4 \pm 14.7^{c}$ & $184.2 \pm 4.6^{\mathrm{a}}$ & $109.8 \pm 7.9^{\mathrm{a}}$ & $68.5 \pm 4.3^{\mathrm{a}}$ \\
\hline & L-56+SAP & $210.2 \pm 1.9^{\mathrm{a}}$ & $236.6 \pm 2.4^{\mathrm{a}}$ & $254.4 \pm 1.0^{\mathrm{a}}$ & $237.7 \pm 2.0^{\mathrm{a}}$ & $182.9 \pm 2.1^{\mathrm{a}}$ & $140.3 \pm 1.4^{\mathrm{a}}$ & $61.9 \pm 6.7^{\mathrm{a}}$ \\
\hline \multirow{4}{*}{ Cucumber } & BJ-18 & $110.7 \pm 3.3^{c}$ & $129.1 \pm 1.5^{\mathrm{d}}$ & $127.2 \pm 4.9^{c}$ & $116.3 \pm 12.1^{\mathrm{d}}$ & $83.6 \pm 5.4^{c}$ & $53.8 \pm 3.9^{c}$ & $9.7 \pm 0.6^{d}$ \\
\hline & L-56 & $184.0 \pm 12.9^{\mathrm{b}}$ & $195.2 \pm 1.8^{b}$ & $156.8 \pm 5.2^{b}$ & $144.5 \pm 5.7^{\mathrm{c}}$ & $99.8 \pm 10.4^{\mathrm{c}}$ & $45.1 \pm 2.9^{c}$ & $18.4 \pm 0.3^{\mathrm{c}}$ \\
\hline & BJ-18 +SAP & $116.4 \pm 2.6^{c}$ & $154.8 \pm 8.4^{\mathrm{c}}$ & $161.7 \pm 3.2^{b}$ & $188.0 \pm 6.5^{\mathrm{b}}$ & $158.7 \pm 10.6^{b}$ & $94.5 \pm 2.6^{b}$ & $54.0 \pm 2.6^{b}$ \\
\hline & L-56+SAP & $213.0 \pm 3.9^{\mathrm{a}}$ & $240.9 \pm 3.2^{\mathrm{a}}$ & $317.2 \pm 2.1^{\mathrm{a}}$ & $331.7 \pm 2.5^{\mathrm{a}}$ & $240.9 \pm 11.8^{\mathrm{a}}$ & $113.5 \pm 6.0^{\mathrm{a}}$ & $75.0 \pm 2.8 \mathrm{a}$ \\
\hline
\end{tabular}

Values are given as mean $\pm \mathrm{SE}$ of three independent biological replicates, and bearing different letters (a, b, c) at one specific time (e.g. 14 or 19 days) are significantly different from each other according to the least significant difference (LSD) test (p<0.05), D: day, SAP: Super Absorbent Polymer, BJ-18: P. beijingensis strain BJ-18, L-56: Bacillus sp. strain L-56. 